WIDER Working Paper 2016/123

\title{
Links between foreign direct investment and human capital formation
}

Evidence from the manufacturing sector in India

Gunja Baranwal*

November 2016 
Abstract: This paper is related to the literature on the effect of foreign direct investment (FDI) on the labour market of host countries. Labour market literature has focused on the demand side of FDI; that is, increasing wage inequality by demanding more skilled workers or just increasing the overall average wages. On the supply side, FDI can enrich the skilled labour force of the host country by provision of on-the-job training or learning or through indirect technological spillover effects. This paper takes into account both these effects and tests for human capital formation effect of FDI in India for core manufacturing sector firms for the period 2001-15 using the Prowess database of the Centre for Monitoring Indian Economy. It also takes into account the endogeneity of decision-making on the part of foreign firms in locating FDI. Five different determinants of FDI are used: market size, distance from main market area, length of national highways, availability of non-agricultural land, and a cast and religion fractionalization index. The most significant factor determining FDI is market size and the distance from main market area and fractionalization index. Different dynamic panel data methods are used with static and dynamic generalized method of moments techniques. This study does not find any positive supply side human capital formation effects of FDI, but finds positive demand side effect of FDI of raising wage inequality and average wages. The results remain robust while taking into account heterogeneities at region, industry, size, and age of the firms.

Keywords: foreign direct investment, human capital, labour demand, labour supply, wages JEL classification: F24, J31, J24

Acknowledgements: I wish to thank the United Nations University World Institute for Development Economic Research (UNU-WIDER), Helsinki, for support during the $\mathrm{PhD}$ internship, where this study was completed. I thank my mentor Miguel Niño-Zarazúa for insightful discussions. I also thank Sugata Matjit, Smriti Sharma, and the participants at the internal seminar at UNU-WIDER for very useful comments.

* Centre for Studies in Social Sciences, Calcutta, West Bengal, India; baranwalgunja@gmail.com.

This study has been prepared within the UNU-WIDER PhD internship programme.

Copyright (C) the Author

Information and requests: publications@wider.unu.edu

ISSN 1798-7237 ISBN 978-92-9256-167-3

Typescript prepared by Ayesha Chari.

The United Nations University World Institute for Development Economics Research provides economic analysis and policy advice with the aim of promoting sustainable and equitable development. The Institute began operations in 1985 in Helsinki, Finland, as the first research and training centre of the United Nations University. Today it is a unique blend of think tank, research institute, and UN agency_providing a range of services from policy advice to governments as well as freely available original research.

The Institute is funded through income from an endowment fund with additional contributions to its work programme from Denmark, Finland, Sweden, and the United Kingdom.

Katajanokanlaituri 6 B, 00160 Helsinki, Finland

The views expressed in this paper are those of the author(s), and do not necessarily reflect the views of the Institute or the United Nations University, nor the programme/project donors. 
Countries first bought the idea of foreign direct investment (FDI) as they found it a convenient and fast tool to finance their growth process without having to invest their own resources, especially in case of financial constraints. However, the strategy to benefit from FDI could also go wrong and hurt the already protected industries in economies worldwide. Having done the cost-benefit analysis, economies slowly started opening up to multinational enterprises. At the time of writing, almost three decades of literature has been developed on FDI's impact on host economies. The topic gained attention owing to its propitious impact on macro and micro economic factors. The reform process in India began after 1990 with the opening up of sectors for foreign capital as a result of easing the regulatory environment for different industries. Since then, FDI in India has surged from US\$2428 million in 2000 to US $\$ 712,587$ million in 2016 (see DIPP 2016a). The literature on the effect of FDI on host countries is diverse.

The literature on macro-economic effects tried to identify possible channels of increases in the economic growth of host countries, such as investment, technologies, and financial capabilities (Agosin and Mayer 2000; Borensztein et al. 1998; de Mello 1999). However, many studies also focused on the micro economic impacts of FDI on host countries. One of the most significant micro impacts is productivity gain from FDI. Although indirect, yet the most explored channel of this effect is estimation of productivity increases via production function to find support for the possible technology transfers from foreign firms to domestic firms, formally called 'spillover effects'. The results vary from developed to developing countries. Javorcik (2004) reports successfully finding positive spillovers to domestic firms for the case of Lithuanian firms through backward linkages in upstream sectors. Blomström (1986) finds competition between foreign and domestic firms to be a channel of productivity increases in modern sectors of Mexican economy. Keller and Yeaple (2009) find stronger positive productivity gains than importing spillovers for manufacturing firms in the United States. Girma and Görg (2005) report that, for a set of firms in the United Kingdom, absorptive capacity matters for productivity gain of foreign technology, and can be plotted with a U-shaped curve. Haddad and Harrison (1993) find less productivity dispersions in sectors with presence of foreign firms but no evidence of productivity gains for Moroccan firms. In the developing and emerging market economies, Aitken and Harrison (1999) find that joint ventures create spillover effects for Venezuelan plants. Dua et al. (2011) test spillover effects of foreign firms on labour productivity of Indian manufacturing firms for 2000-07. They test for inter-cluster technology spillovers in ten clusters across India. Their results show variation across clusters, with some clusters found to have positive effects of spillover compared with others. In contrast, Sasidharan and Kathuria (2011) find no significant horizontal spillover effects of FDI.

Along with productivity spillovers, direct effects on the labour market come from FDI affecting human capital of host countries. Foreign firms form skills by providing on-the-job training to their employees. Tan and Batra (1997), using firm level data for Colombia, Mexico, and Taiwan, find that large export manufacturing, high-technology firms are more likely to invest in training a more educated, more skilled, and unionized labour force than domestic firms. Ritchie (2002) sketches Southeast Asian countries' experience of training provided by multinational enterprises (MNEs). Inward FDI also raises level of human capital indirectly by subsequent spillovers to other firms via labour turnovers and spin-offs (Blomström 1986; Caves 1974; Markusen 1995). Kathuria (2001) discusses positive spillover effects of foreign firms on the productivity of domestic firms in India using panel data for 368 medium- and large-sized Indian manufacturing firms for the period 1975-76 to 1988-89. In the long term, they contribute to the generalequilibrium incentive of individuals in host countries to acquire skills through education and/or 
training. If individuals in host countries have access to these methods of skills acquisition, then they should respond to the price signals coming from the labour market (Slaughter 2002).

The existing political system also plays a key role in processing the effect of multinational enterprises on the labour market. According to Kapstein (2002), the political economy pathways are responsible for the effects of MNE training policies. The role of policy design and its implementation by government is significant here to tailor coordinated policies required for skill upgradation. Government help in creating human capital comes at three levels: (i) general supply of technically trained resources, (ii) matching supply and demand through active firm participation in education and training systems, and (iii) encouraging indigenous firms and MNEs to upgrade technology over time. Countries are investing in new ways of education by improving the coherency of demand and supply of required skills with integrated relationships between educational institutions and industries. Governments can also provide incentives to firms for training that would efface market failures of information constraints, credit constraints, and labour turnovers. However, the roots of vocational training systems depend on a fully developed general education system. As an example, Singapore has a reformed educational and training system with a bias towards technological, scientific, and industrial skills. It has tied the vocational training system to specific industrial sectors and skill needs, especially at the tertiary level. It has formulated a single national education system, selected English as a medium of instruction, mandated 12 years of education, and focused the curriculum on technology. Singapore's Skill Development Fund, Malaysia's Human Resource Development Fund, and the Penang Skill Development Centre represent coordination among government, business, and academia in supplying skills. Financial incentives, public research institutes, and local supplier upgrading are other ways of encouraging private firms to invest in training (Ritchie 2002: 28). A case study of Argentinian human capital formation by Narula and Marin (2005) brings forth the evidence that more skilled employment in MNEs compared with domestic firms, and firms with higher level of absorption created by high investments in training, experience more spillover effects.

Besides these supply side effects, FDI also affects the demand for labour in host countries either on average or relative wages. The literature is replete with effect of FDI on wage inequality especially for developing countries. Feenstra and Hanson (1997) find increases in skilled wages for Mexican workers relative to unskilled workers, and this increase is related to increases in FDI in Mexico's manufacturing sector by multinationals in the United States for the period 1975-88. Figini and Görg (2006) find non-linear effect of FDI on wage inequality for a panel of 100 OECD (Organization for Economic Cooperation and Development) and non-OECD countries for the period 1980-2002. Using generalized method of moments (GMM) with internal instruments their study finds that non-OECD countries initially show a positive trend of increase in wage inequality but this effect reduces with time. On the other hand, OECD countries experience a reduction in wage inequality over time and do not show a non-linear effect. Indian wage inequality has been widely studied (Azam 2010; Chamarbagwala 2006; Hasan et al. 2007; Ramaswamy 2008). This paper attempts to take into account both demand and supply effects and test for human capital formation in the Indian manufacturing sector. The paper is organized as follows. Section 2 shows the trend of FDI in India. Section 3 sketches the human capital formation. Section 4 discusses the theoretical framework, with subsections dealing with the issue of endogeneity and instruments. Section 5 discusses data and distribution of firms. Results and discussion appear in Section 6, and Section 7 concludes. 


\section{Trend of FDI in India}

FDI in India has soared over the years with cumulative FDI inflow of US\$424,167 from April 2000 to March 2016 (Table 1). Currently, an Indian firm is allowed to receive FDI under two routes: one is the automatic route, where no prior permission is required for investment; foreign firms can invest on the basis of different sectoral caps changed by the government from time to time. The other is the government route, for sectors not covered under the automatic route; here, firms require applying to the Foreign Investment Promotion Board, Department of Economic Affairs, Ministry of Finance, Government of India, to get approval. ${ }^{1}$ The movement of sectors from government route to automatic route was slow but gained momentum after 2000 and especially after 2006 when FDI jumped from US $\$ 4029$ million to US $\$ 22,826$ and to US $\$ 55,457$ in 2016 (DIPP 2016b).

Table 1: Foreign direct investment (FDI) inflow to India (March 2001-April 2016)

\begin{tabular}{lcc}
\hline Financial year & FDI inflow (in US\$ million) & $\begin{array}{c}\text { Percentage change in FDI flow over } \\
\text { previous year }\end{array}$ \\
\hline $2000-01$ & 2463 & +65 \\
$2001-02$ & 4065 & -33 \\
$2002-03$ & 2705 & -19 \\
$2003-04$ & 2188 & +47 \\
$2004-05$ & 3219 & +72 \\
$2005-06$ & 5540 & +125 \\
$2006-07$ & 12,492 & +97 \\
$2007-08$ & 24,575 & +28 \\
$2008-09$ & 31,396 & -18 \\
$2009-10$ & 25,834 & -17 \\
$2010-11$ & 21,383 & +64 \\
$2011-12$ & 35,121 & -36 \\
$2012-13$ & 22,423 & +8 \\
$2013-14$ & 24,299 & +27 \\
$2014-15$ & 30,931 & +29 \\
$2015-16$ & 40,001 & \\
\hline
\end{tabular}

Source: FDI factsheets (DIPP 2016b).

Figure 1 depicts the distribution of FDI across different sectors from January 2000 to March 2016. There was some fluctuation in FDI inflows as shown by the percentage changes in FDI inflow, with the maximum positive upsurge occurring in 2006. Construction, automobiles, pharmaceuticals, chemicals, and metal are the sectors attracting the largest FDI in the manufacturing sector after the services sector. As shown in Figure 1, FDI is more concentrated in the chemicals, automobile, construction, and machinery industries compared with textiles, food and metallurgical industries. Drawing inference from Figure 1, FDI seems to be more concentrated in the heavy industries or those requiring a high-skilled labour force.

\footnotetext{
${ }^{1}$ For frequently asked questions on foreign investments in India, see Reserve Bank of India (2015).
} 
Figure 1: Subsector-wise distribution of foreign direct investment (FDI) (in USD) in the manufacturing sector in India (January 2000 to March 2016)

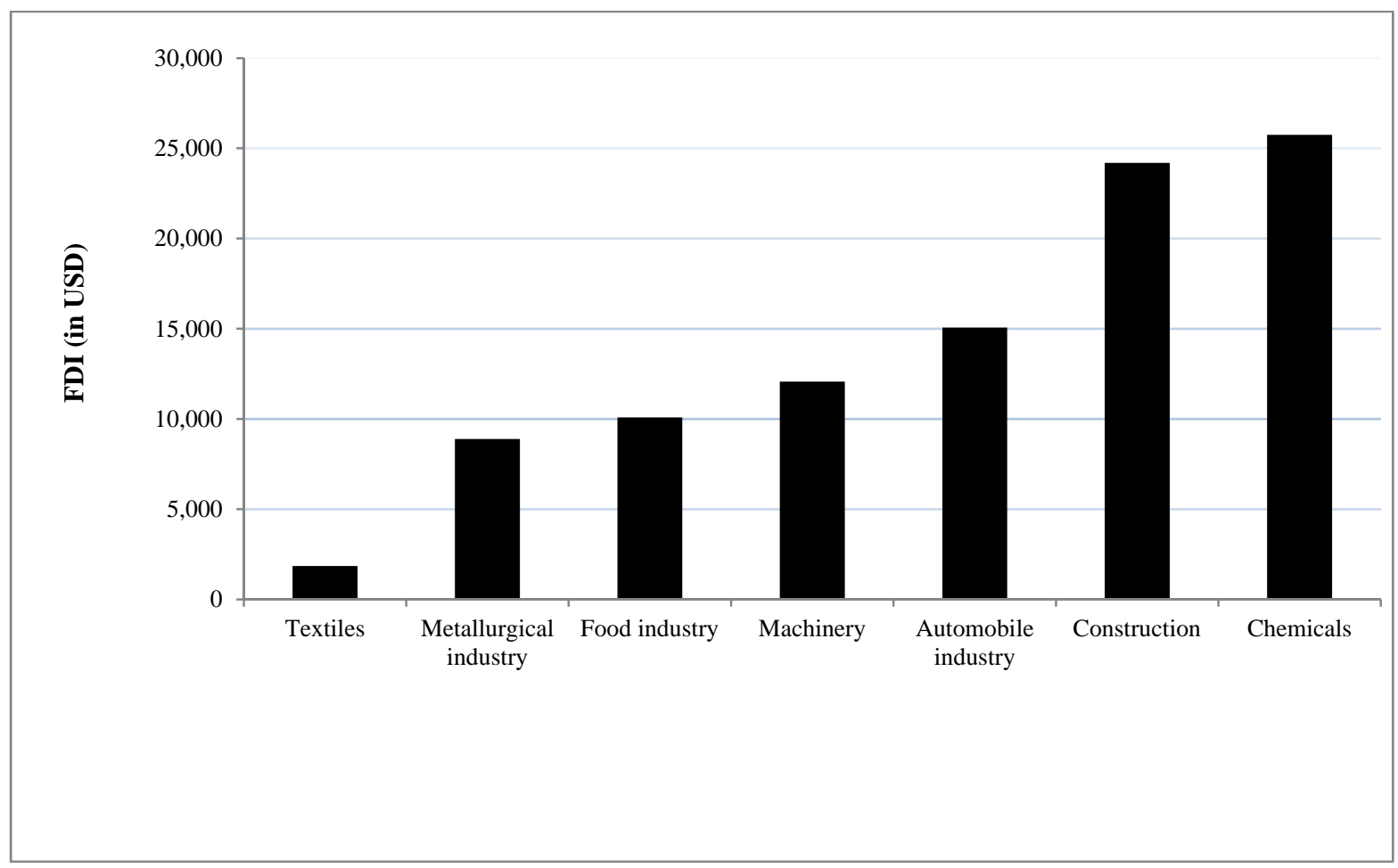

Source: Author's compilation based on FDI Statistics, Department of Industrial Policy \& Promotion, Government of India.

Geographically, FDI is clustered in some economically advanced regions that have attracted/accounted for the largest share of FDI inflows. These include the regions of Mumbai, New Delhi, Chennai, Bangalore, Ahmedabad, and Hyderabad. On the other hand, regions such as Kanpur, Bhopal, Patna, Bhubaneswar, Jaipur, and those of the North East have received a very small amount of FDI inflow. Figure 2 shows the region-wise distribution of FDI for the period January 2000 to March 2016.

Figure 2: Region-wise distribution of FDI (in USD) in India (January 2000 to March 2016)

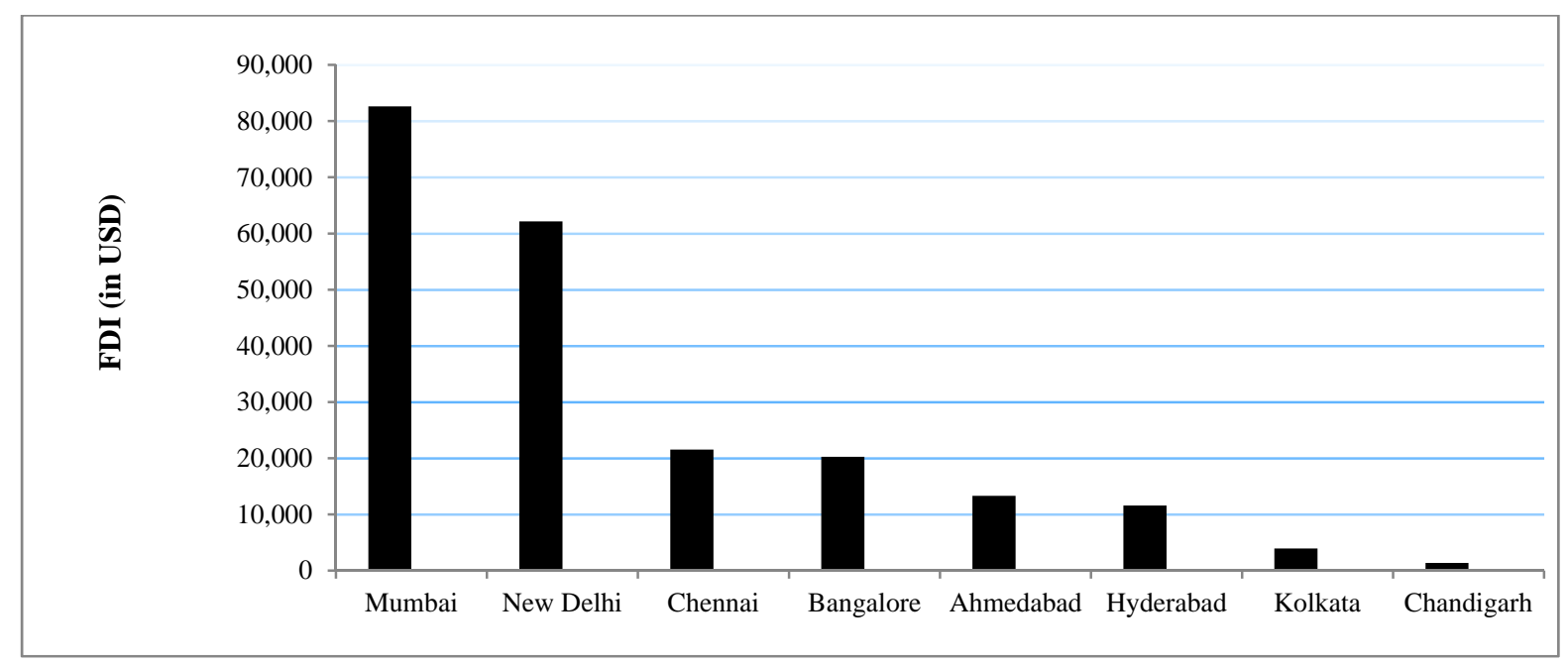

Source: Author's compilation based on FDI Statistics, Department of Industrial Policy \& Promotion, Government of India. 
Ghosh (2016) find evidence of a large demographic dividend for the backward Indian states for the period 1961-2011. Large states such as Uttar Pradesh, Madhya Pradesh, Rajasthan, and Haryana are found to have the highest demographic dividend. Aiyar and Mody (2011) find that the demographic dividend can contribute to two percentage points annually to the gross domestic product over the next two decades-from 2020 to 2030-owing to increases in working age population. Human capital has increased over the years. Figure 3 depicts the increase in total number of higher education institutes in India over the years. This includes available total colleges and universities across the country. Similarly, there has been an increase in gross enrolment ratios in senior secondary and higher education levels over the last decade from 2000 to 2014.

Figure 3: Human capital formation in India (1990-2014)

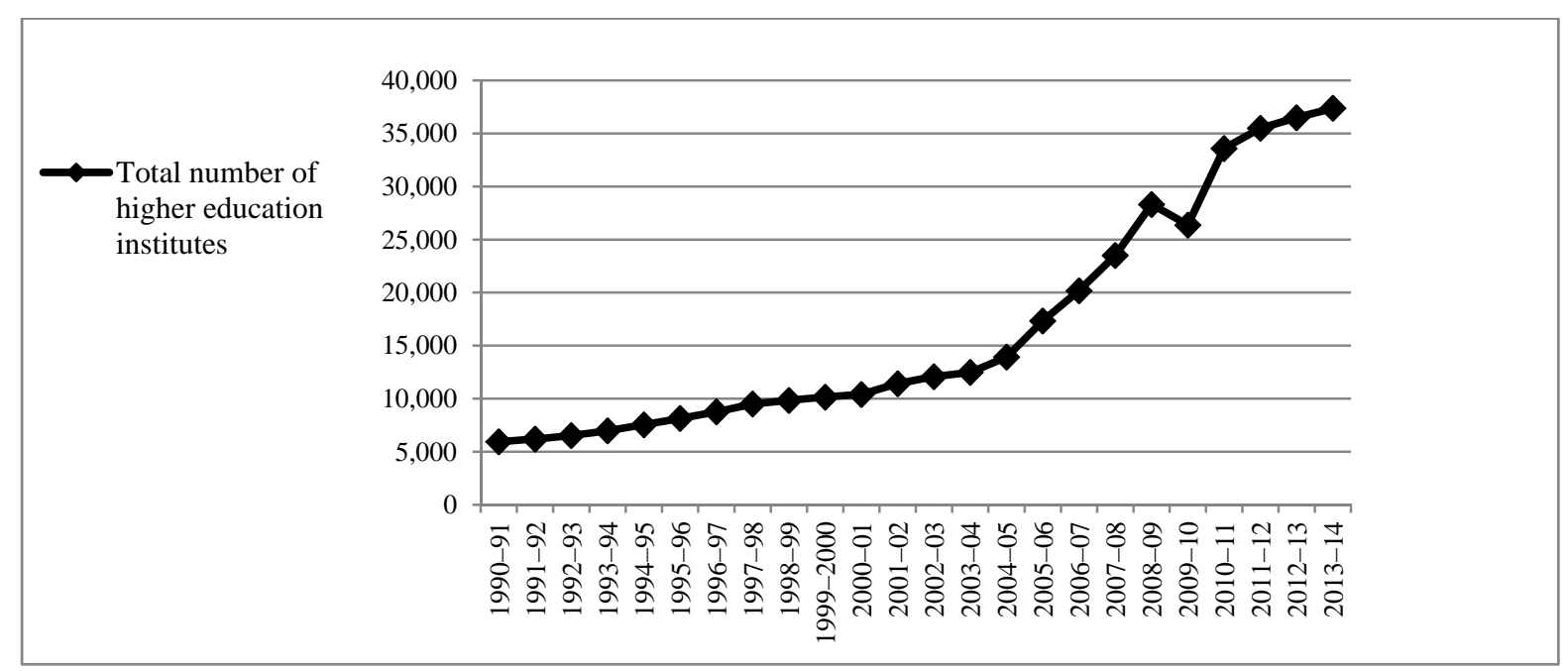

Source: Author's illustration based on data from MHRD (2014).

Figure 4: Human capital trend (gross enrolment ratios, GERs, in secondary and higher education) in India

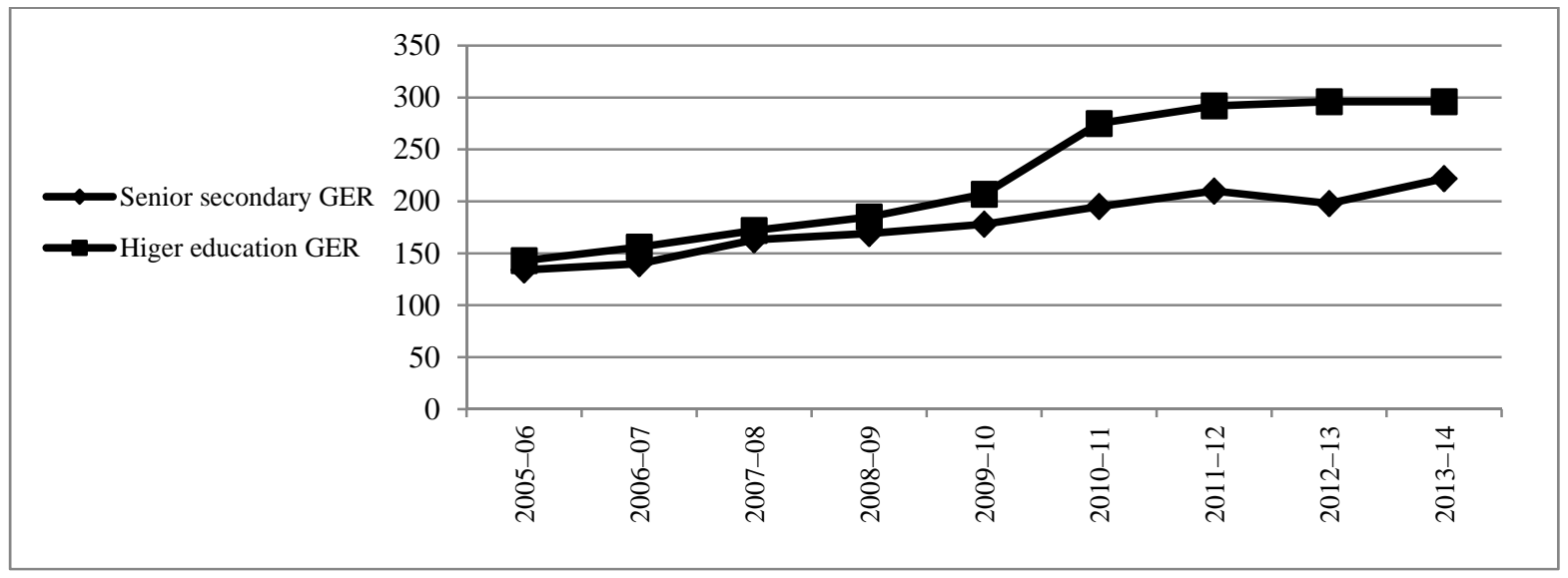

Source: Author's illustration based on data from MHRD (2016). 
This paper is led by theoretical modifications Katz and Murphy (1992) and Te Velde and Morrissey (2004). Assume a two-factor constant elasticity of substitution production function with low-skilled labour $(U)$ and high-skilled labour $(S)$ as two inputs:

$$
\begin{aligned}
& f\left(U_{t}, S\right)=\left\{\lambda\left(\psi_{U t} U_{t}\right)^{\rho}+(1-\lambda)\left(\psi_{S t} S_{t}\right)^{\rho}\right\}^{\frac{1}{\rho}} \\
& \varphi_{U t} \equiv \ln \psi_{U t} ; \varphi_{U t}=\gamma_{1 U} t+\gamma_{2 U} F S ; \varphi_{S t} \equiv \ln \psi_{S t} ; \varphi_{S t}=\gamma_{1 S} t+\gamma_{2 S} F S,
\end{aligned}
$$

where $\varphi_{U t} \equiv \ln \psi_{U t}$ and $\varphi_{S t} \equiv \ln \psi_{S t}$ are functions of labour efficiency units and parameter $\rho<1$. We can interpret labour efficiency index in terms of accumulated human capital. The elasticity of substitution between $U$ and $S$ is $\sigma=1 / 1-\rho$. There can be many changes in technology as a result of different factors such as FDI and interaction terms of FDI with various firm level characteristics. In other words, these are some ways by which FDI can affect the labour market. These demand shift factors can include FDI and international trade. ${ }^{2}$ The labour efficiency indices are a function of share of foreign promoters in equity shares FS (Te Velde 2001), interaction term $F S_{i t} \times \operatorname{train}_{i \text { ir }}$ and firm level factors such as training expenses and size. ${ }^{3}$ This study includes interaction term FDIxtraining expense of firms to assess the human capital formation process undertaken by foreign firms.

Solving for first-order condition and keeping marginal productivity equal to factor prices gives the formula for relative wages of skilled-unskilled labour:

$$
\ln \left(\frac{W_{S}}{W_{U t}}\right)=\ln \left(\frac{1-\lambda}{\lambda}\right)-\frac{1}{\sigma} \ln \left(\frac{S}{U_{t}}\right)+\frac{\sigma-1}{\sigma} \lambda_{1} F S_{t}+\varepsilon_{t},
$$

where $\gamma_{1}=\gamma_{1 S}+\gamma_{1 U}$ and $\gamma_{2}=\gamma_{2 S}+\gamma_{2 U}$; thus, wage inequality is the function of a supply term (relative supply of high- to low-skilled labour and FDI, i.e. foreign share). $\gamma_{1}$ shows the effect of FDI on wage inequality, and a positive (negative) $\gamma_{1}$ tends to increase (decrease) wage inequality.

The starting point of estimation is the demand and supply Equation (4), where demand is the dependent variable of relative wages and supply is the independent variable of relative employment with other control variables.

$$
\begin{aligned}
\ln \{r l w\}_{i j d s t} & =\alpha_{i}+\beta_{1} \ln \left\{\text { rlemp }_{i j d s t}+\beta_{2} F_{S_{j d s t}}+\beta_{3} \text { train }_{i j d s t}+\beta_{4} F_{S_{i j d s t}}\right. \\
& \times \operatorname{train}_{i j d s t}+\beta_{5} \text { size }_{i j d s t}+\beta_{6} \operatorname{size}_{i j d s t}^{2}+u_{i}+v_{j}+\rho_{d}+\sigma_{S}+s_{t}+\varepsilon_{i t}
\end{aligned},
$$

The problem with the estimation of this equation is that existence of demand and supply variables in the same equation creates endogeneity in the system. As we are not interested in

\footnotetext{
${ }^{2}$ For more detail on the effect of foreign direct investment (FDI) on wage inequality, see Chamarbagwala (2006), Feenstra and Hanson (1997), Figini and Görg (2006), Görg and Stroble (2002), and Ramaswamy (2008).

${ }^{3}$ Kathuria (2001) also empirically tests the interaction term foreign sharex research and development indices.
} 
identifying demand and supply curves but rather in estimating the human capital formation effect of FDI, the relative employment term is dropped from Equation (4) to give Equation (5): ${ }^{4}$

$$
\begin{aligned}
\{r l w\}_{i j d s t} & =\alpha_{i j d s t}+\beta_{1} F S_{i j d s t}+\beta_{2} \text { train }_{i j d s t}+\beta_{3} F S_{i j d s t} \times \text { train }_{i j d s t}+\beta_{4} \text { size }_{i j d s t} \\
& +\beta_{5} \text { size }_{i j d s t}^{2}+u_{i}+v_{j}+\rho_{d}+\sigma_{S}+\varsigma_{t}+\varepsilon_{i t}
\end{aligned} .
$$

The underlying assumption now is that relative employment is given and the aim is to estimate the changes in relative wages caused by FDI, on-the-job training, and other firm level factors and their interaction terms. The dependent variable is relative wages, which represents labour demand. It is a ratio of skilled to unskilled wages; it is also a ratio of wages and salaries paid by firms, as documented in the Prowess database (CMIE 2016), to the average wages of the rural sector $^{5}$ for men at an all-India level, as recorded by the Labour Bureau (2012-13) and the Reserve Bank of India (n.d.). The main independent variables are FDI, on-the-job training, size, and size squared. The focus is on the coefficient of interaction term of foreign sharextraining or the coefficient $\beta_{3}$. This coefficient measures the effect of training expenses for different values of foreign share on relative wages; $\beta_{1}$ measures the effect of foreign share on relative wages with zero on-the-job training expenses and $\beta_{2}$, the effect of training expenses with foreign share equal to zero. Thus, the interaction term allows us to look at the respective demand and supply side effects of FDI on the labour market. A positive coefficient of $\beta_{3}$ would indicate that the supply side effects of FDI are not strong enough to mitigate the demand side effect, resulting in wage inequality. Tables 2 and 3 present summary statistics and validity test results used in this model (for a definition of all variables, see Appendix A).

Table 2: Summary statistics

\begin{tabular}{lcccc}
\hline Variables & Mean (1) & Standard deviation (2) & Minimum (3) & Maximum (4) \\
\hline Foreign share & 26.12 & 26.10 & 0 & 96.8 \\
Training & 25.99 & 92.02 & 0 & 1630.1 \\
Foreign share Training & 901.16 & 4290.44 & 0 & $67,681.75$ \\
Size & 4749.66 & $25,584.40$ & 0 & $77,6324.1$ \\
Size & $6.77 \mathrm{e}+08$ & $1.32 \mathrm{e}+10$ & 0 & $6.03 \mathrm{e}+11$ \\
Relative wages (rural) & 1.60 & 5.36 & 0 & 76.55 \\
Relative wages (industrial) & 1.10 & 3.51 & 0 & 66.68 \\
Instruments & & & 12.40 & 19.11 \\
Log population & 17.96 & 0.82 & 0 & 10.65 \\
Log market distance & 1.73 & 2.48 & 4.77 & 23.02 \\
Log non-agricultural land & 14.63 & 5.42 & 0 & 42 \\
Log length of national highways & 3.81 & 3.11 & 0.48 & 0.99 \\
Fractionalization & 0.96 & 0.05 & & 0.96 \\
\hline
\end{tabular}

Source: Author's compilation based on study dataset.

Equation (5) can be estimated with pooled ordinary least-squares estimators, but the estimates can be biased and inconsistent. As firm level data are available, another option is applying the fixed-effects estimation taking into account the unobserved fixed effects. However, the problem

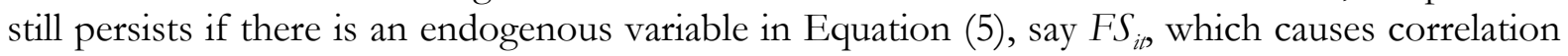
between $F S_{i t}$ and $\varepsilon_{i t}$. This leads us to use the instrumental variable (IV) estimation strategy that allows introducing external instruments and takes care of the possible endogeneity in the system.

\footnotetext{
${ }^{4}$ The $\log$ specification is also dropped as the focus is not on estimating the elasticity of substitution.

5 The rural sector includes activities such as ploughing, sowing, weeding, transplanting, harvesting, winnowing, threshing, picking, well digging, and cane crushing; it also consists of herdsmen, carpenters, blacksmiths, cobblers, masons, tractor drivers, sweepers, and unskilled labourers (Labour Bureau 2012-13).
} 
Table 3: Test results for validity of instruments

\begin{tabular}{lc}
\hline Instruments & Montiel-Pflueger robust weak instrument test \\
\hline Log of population & 10.780 \\
Log of non-agricultural land & 6.572 \\
Log of distance from main market area & 10.953 \\
Log national highways & 9.696 \\
Fractionalization index & 9.526 \\
\hline
\end{tabular}

Source: Author's compilation based on study dataset.

For IV regressions, the following models are used:

$$
\begin{aligned}
& F S_{i j d s t}=\alpha_{i j d s t}+\beta x_{i j t}+\vartheta z_{s t}+u_{i}+v_{j}+\rho_{d}+\sigma_{s}+\varsigma_{t}+e_{i t}, \\
& r l w_{i j d s t}=\alpha_{i j d s t}+\beta x_{i j d s t}+\phi F S_{i j d s t}+u_{i}+v_{j}+\rho_{d}+\sigma_{s}+\varsigma_{t}+\varepsilon_{i t},
\end{aligned}
$$

where $\tau_{s t}$ consists of a vector of strictly exogenous IVs that are partially correlated with $F S_{i j t}$ and uncorrelated with $r w_{j i t}$ More formally, $\vartheta \neq 0$ and the covariance $\operatorname{cov}\left(\gamma_{i j}, e_{i t}\right) \neq 0$; thus, $\gamma_{j i t}$ is correlated with $F S_{i j t}$ and $\operatorname{cov}\left(\gamma_{i j}, \varepsilon_{i t}\right)=0$, but uncorrelated with $r l w_{i j t}$. However, it is difficult to come up with a strong instrument that can serve as a proxy for foreign share. Here, the MontielPflueger test for weak instruments is used (see Pflueger and Wang 2015), which is also an extension of Stock and Yogo (2002), to compare estimator 'Nagar bias' relative to 'worst case' benchmark two-stage least squares (2SLS) and limited information maximum likelihood (LIML) estimator with a single endogenous variable, foreign share in this case. The rejection of the test depends on effective $F$ statistic that exceeds critical value significance level of $\alpha$ and desired threshold $\tau$.

Different methods of static IV estimation are explored to check for the robustness of study results. 2SLS, GMM, LIML, continuously updated estimator (CUE), IV fixed effects, and extended 2SLS are applied.

However, there can be other sources of endogeneity in the system, which leads to incorporating the endogeneity in other variables thus giving more robust estimates. Dynamic system GMM is applied and analysis is extended by including the external instruments in a dynamic setting. Thus, the equation now becomes:

$$
r l w_{i j d s t}=\alpha_{i j d s t}+\varphi r l w_{i j d s t-1}+\beta x_{i j d s t}+\phi F S_{i j d s t}+u_{i}+v_{j}+\rho_{d}+\sigma_{s}+\varsigma_{t}+\varepsilon_{i t},
$$

where $\phi$ is the parameter estimate of the lagged dependent variable $r l w_{i j d s \uparrow 1}$. The Blundell-Bond system GMM is used for estimating Equation (8) (see Blundell and Bond 1998). The superiority of this estimator comes from the fact that it uses the information from lagged differential instruments to solve the level equation and then uses the lagged levels of endogenous variables as instruments for the first differential equation (Gisselquist et al. 2016).

\subsection{Instruments set}

The effect of FDI-crucial for economic growth literature-is also grounded in the characteristics of a host country. Alfaro et al. (2004) report that developed financial markets may help host countries gain from FDI. Using cross-country analysis, they support the idea that countries with better financial systems can provide credit to entrepreneurs and thus benefit from FDI via backward linkages. They also find that the presence of high-skilled human capital helps 
benefit from FDI. Borensztien et al. (1998), using cross-country data for developing countries, find that economic growth effects of FDI are stronger than domestic investment effects given the presence of good quality human capital. In the work by Noorbakhsh et al. (2001), the decision to invest in a host country may depend on the level of human capital in an economy. They measure human capital as enrolments in secondary education, and find that human capital is a significant determinant of FDI for the period 1980-94 for 36 developing countries.

The present study takes into account that FDI inflow in a host country is dependent on many factors including size of the market in the host country and availability of cheap resources. This allows the use of various available instruments at state level: five different instruments are used to check the validity of Equation (5).

Size of market is a strong determinant of inward FDI in a host country. Nunnenkemp and Mukim (2011) find 1 per cent increase in market size increases the chance of attracting an investor by 16 per cent. The idea is related to scale of economies: the larger the size of market, the larger is the incentive for a foreign firm to expand and enjoy the economies of scale by increasing production. Log of population is used to instrument for FDI.

Distance from main market area can affect the costs of a firm. Firms will always try to reduce the distance between the manufacturing plant and the main market area. The economies of scale work here too. Thus, firms will try to be located nearest a market area. The distance between the manufacturing plant and the main market area in the particular state is used to instrument for FDI.

Good infrastructure serves as a basic condition to attract foreign firms in an area. Cities with better infrastructure are most likely to attract higher FDI. Two measures of infrastructure are used as instruments: length of national bighways and availability of non-agricultural land. The more nonagricultural land the state has, the easier it is for firms to establish their plants in that area.

The fractionalization index is used to take into account caste and religious heterogeneity in India. The larger the fractionalization, the lesser will be the chances of FDI inflow in a region. Foreign firms will search for safe and better environments to invest in a particular area. This information on states is also used to instrument for FDI.

\subsection{Testing the instruments}

Following the discussion on endogeneity, a suitable instrument for foreign share is determined from the available set of instruments. The Montiel-Pflueger test is used to check for robustness of instruments (Table 3). The instrument $\log$ of population is above the threshold value of 10.780, which suggests it can serve as a good instrument for foreign share. However, it drops to 6.572 when $\log$ of non-agricultural land is applied. Next, log of distance from the main market area is tested and the value is 10.953 , above the threshold of 10 . The value for log of national highways is 9.696 , which is very close to the threshold in Table 3 . The last instrument tested for is the fractionalization index. The value of the index (9.526) is also close to the threshold. Two different specifications are applied: one with all the instruments, and another with those above the threshold level. It also allows testing for the robustness of all coefficients. Besides using them separately in this study, the combination of these instruments was used while testing for both static and dynamic GMM. 


\section{$5 \quad$ Data}

Annual reports of companies containing information on income statements and balance sheets are one of the most important sources of firm level data. This study uses the Prowess database, described as 'the largest and most comprehensive database on the financial performance of Indian business entities' (CMIE 2016). The database covers listed and unlisted large, medium, and small firms of the manufacturing and service sectors. It includes non-financial public and private limited manufacturing firms trading on the National Stock Exchange and the Bombay Stock Exchange. The present study uses unbalanced panel data for manufacturing firms from sectors including metal, chemicals, construction, consumer goods, food, machinery, textiles, and transport equipment for the period 2001-15, and identifies firms by the districts in which they operate. $^{6}$

\subsection{Distribution of foreign firms}

The unbalanced panel includes firms from different age group categories. Figure 5 represents the distribution of foreign firms by age. The largest numbers of foreign firms (30.4 per cent) belong to the age group 43-30 years, followed by 64-44 years (21.59 per cent) and relatively new firms with fewer than 24 years of experience. Thus, more than 50 per cent of foreign firms belong to a relatively 'old' age group. Large part of the study sample includes firms from deciles 1-4. Figure 6 plots the size-wise distribution of foreign firms. The deciles are formed on the basis of threeyear averages of summation of income and assets. Thus, it is based on the last three years' performance of a firm. Almost 70 per cent of Indian firms have been performing better since the last three years.

Figure 7 depicts the distribution of foreign firms across states in India. A large percentage of firms in the study sample (30.85 per cent) are from Maharashtra, followed by Gujarat and Andhra Pradesh (12.8 per cent in both) and Haryana (9.14 per cent). These figures are in line with the macroeconomic figures presented in Figure 2. These are also the states with better infrastructure and resources to attract foreign investors. Figure 8 shows the distribution of foreign firms across industries and is in line with Figure 1. Of the whole sample, 25.18 per cent of foreign firms are in the chemical sector, followed by 21.41 per cent in machinery and 11.6 per cent in the transport equipment or automobiles sector.

\footnotetext{
${ }^{6}$ I tested for attrition in data using an inverse probability method and found 19 per cent attrition, which I corrected by taking into account the weights in estimation. The results are robust to the exclusion of weights in estimation.
} 
Figure 5: Distribution of foreign firms by age

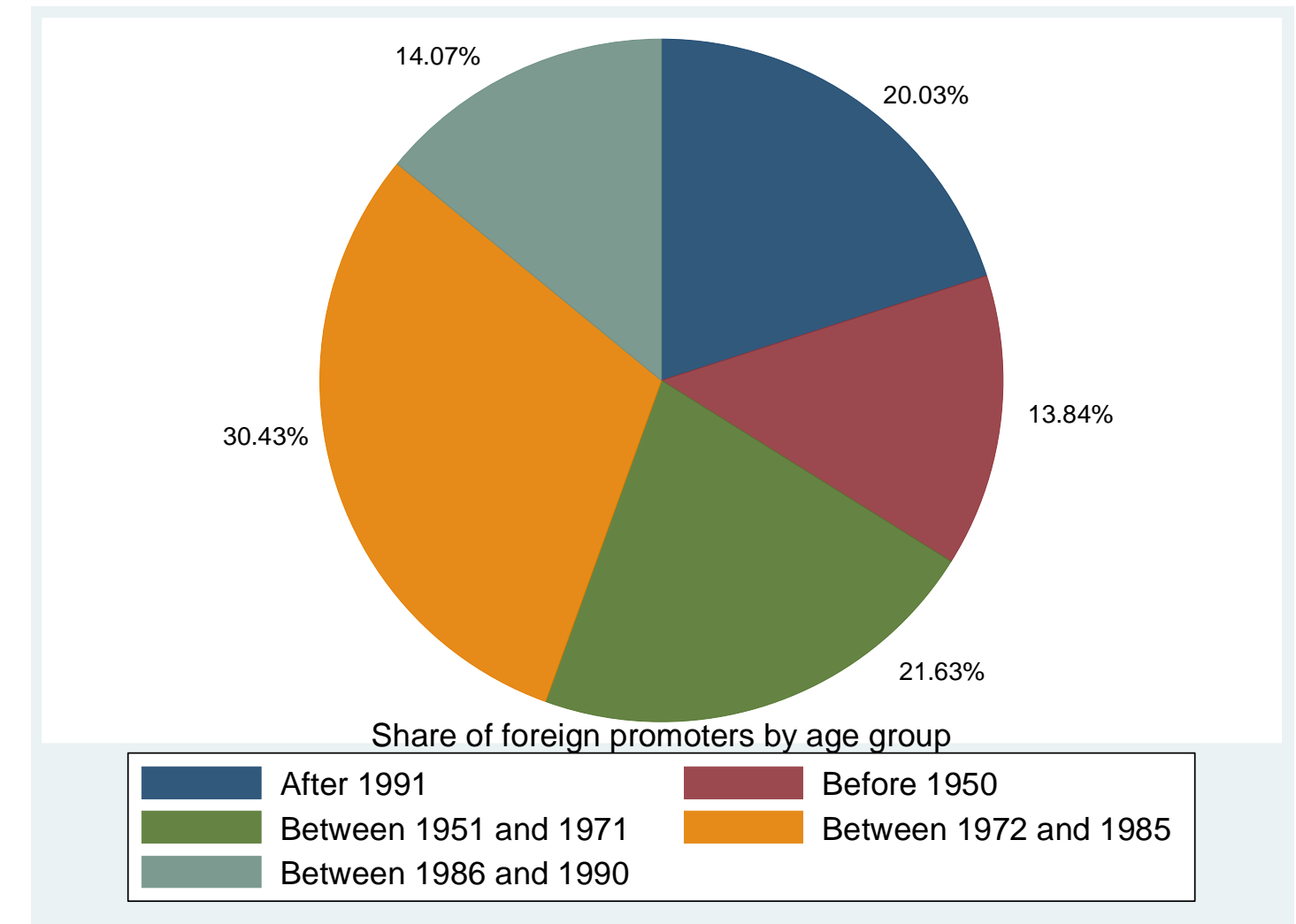

Source: Author's depiction based on calculations and data from the Prowess database (CMIE 2016).

Figure 6: Distribution of foreign firms by size

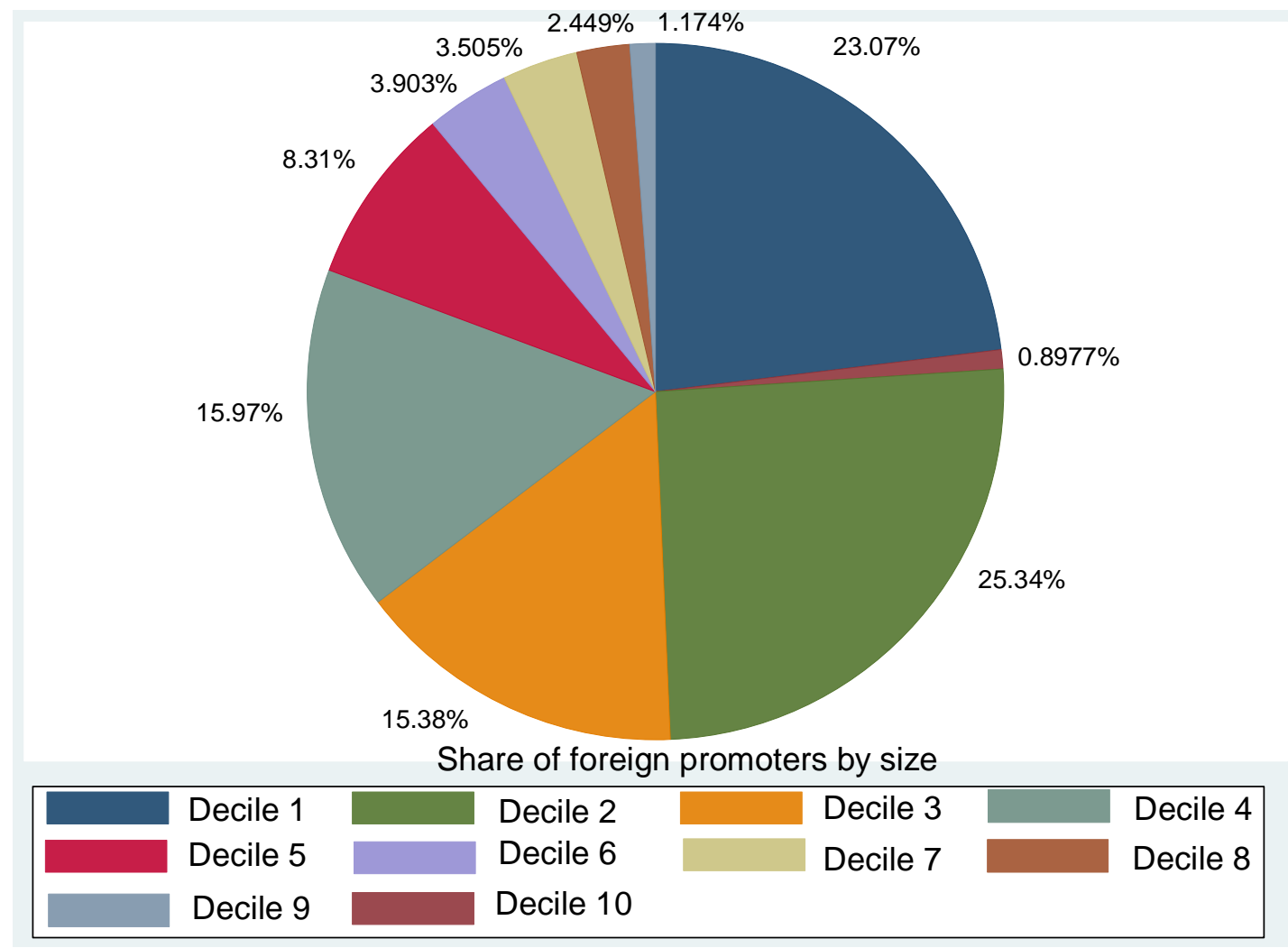

Source: Author's depiction based on calculations and data from the Prowess database (CMIE 2016). 
Figure 7: State-wise distribution of foreign firms

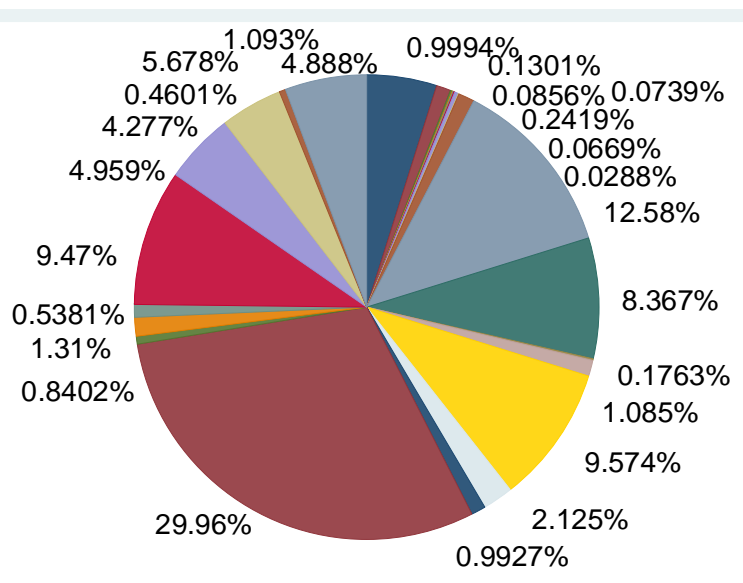

Share of foreign promoters by state

\begin{tabular}{|c|c|c|c|}
\hline New Delhi & Andhra Pradesh & Assam & Bihar \\
\hline Chandigarh & Chattisgarh & Dadra & Daman \\
\hline Goa & Gujarat & Haryana & Himachal Pradesh \\
\hline Jhakhand & Karnataka & Kerala & Madhya Pradesh \\
\hline Maharashtra & Orissa & Punjab & Rajasthan \\
\hline Tamilnadu & Telangana & Uttar Pradesh & Uttarakhand \\
\hline West Bengal & & & \\
\hline
\end{tabular}

Source: Author's depiction based on calculations and data from the Prowess database (CMIE 2016).

Figure 8: Industry-wise distribution of foreign firms

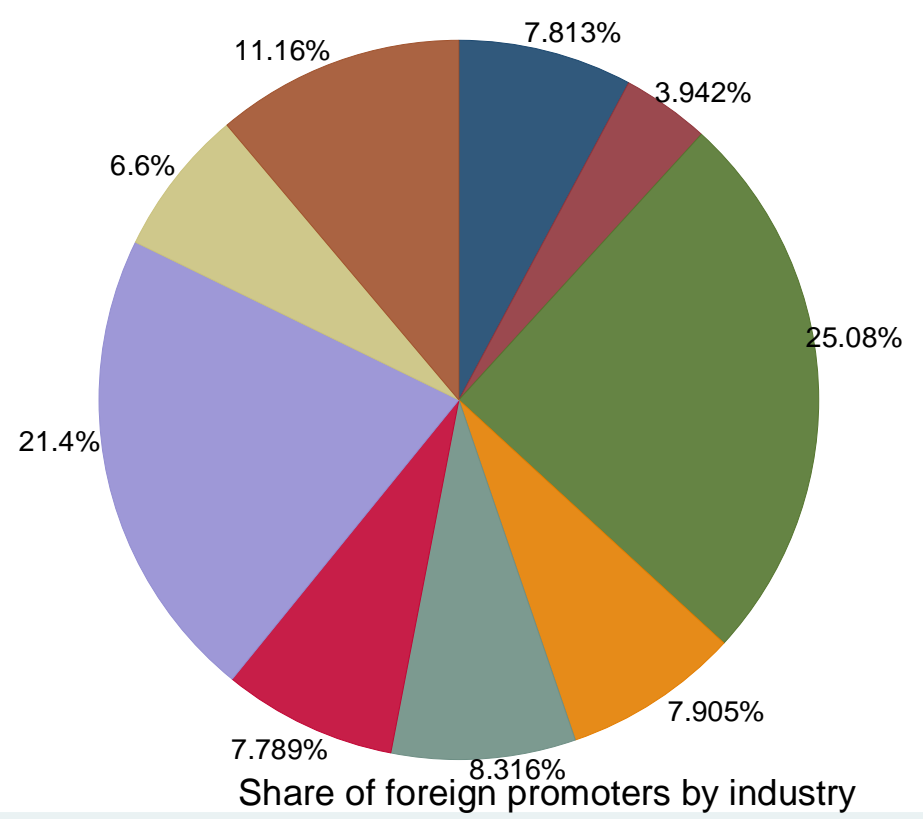

\begin{tabular}{|c|c|c|c|}
\hline Metal & Miscellaneous & Chemicals & Construction \\
\hline Consumer goods & Food & Machinery & Textile \\
\hline \multicolumn{4}{|c|}{ Transport equipment } \\
\hline
\end{tabular}

Source: Author's depiction based on calculations and data from the Prowess database (CMIE 2016). 


\subsection{Static and dynamic GMM results}

This study tested the static IV method first, followed by dynamic versions of the baseline model with different specifications. Two different types of relative wages are used as dependent variables: skilled to unskilled relative wages and industrial relative wages. The latter can also be interpreted as the average wages because it is a ratio of firm wages to industry level wages. The endogeneity of FDI is taken into account and the baseline model is tested with different state level instruments available for FDI. The results use log of population, distance from main market area, length of national highways, availability of non-agricultural land, and the fractionalization index as instruments for FDI.

Appendix Table A1 shows results for the static IV model for the baseline equation with all the instruments and rural relative wages as dependent variables. Positive and significant coefficient of the share of foreign firms in all the different model specifications is found to range from 0.36 for GMM to 0.72 for LIML. The coefficient of CUE is 0.45 . So, 1 per cent increase in the share of foreign firms is associated with $0.36-0.72$ point increase in relative wages based on static IV estimation. The coefficient of training is also positive and significant, as expected, in the CUE model (see column (5), Appendix Table A1). The main coefficient of interest is the interaction term FDIxtraining. All columns (2-5) in Appendix Table A1 with different model specifications show a positive and significant effect of the interaction term FDI xtraining on relative wages. This suggests the significance of demand side effect of human capital formation via on-the-job training by foreign firms. It implies that the demand for skilled workers is more dominant than the supply of skilled workers by foreign firms via on-the-job training. On the basis of the instrument testing, the three most significant instruments are chosen and tested for a combination of $\log$ of population, distance from main market area, and fractionalization on FDI (Appendix Table A2). The results remain robust for all the different specifications (2SLS, GMM, LIML, IV, ExIV2SLS, and CUE) (see columns (1)-(5), Appendix Table A2). The results depict a positive coefficient of $\beta_{3}$; that is, interaction term FDI $\times$ training ranging from 0.001 to 0.0008 , which confirms the previous results. The value of the Kleibergen-Paap rk language multiplier (LM) statistic is also above the threshold level in Ex2SLS and CUE estimations (columns (4) and (5), respectively, Appendix Table A2. The results remain the same when industrial relative wages is regarded as a dependent variable (Appendix Table A3). The coefficient of foreign share now ranges from 0.17 to 0.27 with significance at 5 per cent. However, on-the-job training becomes insignificant. The coefficient of interaction term also remains positive and significant, ranging from 0.001 to 0.0002 indicating validity of the previous results. The coefficient of industrial wages as a dependent variable ranges from 0.001 to 0.009 , whereas for foreign share it increases to 0.46 when only log of population, distance from main market area, and fractionalization are considered (Appendix Table A4). Interaction term remains significant and positive for all the different models.

Appendix Table A5 shows results of applying dynamic GMM with all instruments and the set of significant instruments. Column (1) shows the results for rural wages as the dependent variable along with all the instruments used for foreign share. The coefficient of foreign share drops to 0.20 but remains positive and significant. Taking into account the endogeneity of the system does not affect the interaction term, which remains positive and significant in this model. The Sargan $P$ value of 0.93 and Hansen value of 0.38 confirm the validity of previous results. The effect remains the same with the robust set of instruments (column (2)), with the coefficient of 
foreign share dropping to 0.19 and training becoming positive and significant with a value of 2.42. The coefficient of foreign share and training expenses remains the same. The exercise is repeated for industrial wages as the dependent variable with and without all instruments (in columns (3) and (4), respectively). The interaction term remains positive and significant, although foreign share and training remain positive but become insignificant.

\subsection{Review of results: A discussion}

This section compares the present study with the existing literature on the effect of FDI on host countries. The existing literature on the supply side effects of FDI on a host country's labour market is still at a nascent stage. This study takes into account the demand and supply effects of FDI and endogenizes decision-making on the part of foreign firms to enter into a host country using external instrument. Results confirm the existence of a positive demand side effect of FDI on the labour market by raising wage inequality in a host country. These results seem to be in line with the previous literature. Among other studies on the effect of a firm's expenses on the labour market, Tan and Batra (1997) examine the effect of a firm's 'technology-generating' expenses on wage inequality for Columbia, Mexico, and Taiwan using a cross-section of manufacturing sector firms. Using semi-parametric estimation techniques, they find positive relationship between skilled wages and different firm level characteristics, thus supporting the skill demand hypothesis by firms. They find the effects of research and development (R\&D) and training stronger than that of exports. Ballot et al. (2006), using dynamic panel data methods for French and Swedish firms, find that foreign firms do not distribute the share of labour to workers specifically for R\&D and training investments. The investments in intangible assets are captured better by foreign firms. Baranwal (2016) finds a positive effect of FDI on the demand for high-skilled workers compared with mid- and low-skilled workers, although with a different dataset. Some studies in India find a positive effect of the liberalization process on wage inequality. For example, Chamarbagwala (2006), using a non-parametric methodology specifically by trade and outsourcing, finds increasing within-industry wage inequality biased in favour of skilled labourers. Hasan et al. (2007) also find a positive effect of trade on demand elasticity of labour in the Indian manufacturing sector, and a declined overall share of labour in total output. Azam (2010) finds tertiary and secondary wage premium increasing for the period 1983-2005 owing to reduction in supply of labour for this period. In contrast, using panel data on Venezuelan firms, Aitken and Harrison (1999) find a negative effect of foreign firms on indigenous firms, but they mostly use ordinary least-squares technique for estimation. Fu and Gong (2011) test for a panel of Chinese firms and find high-technology indigenous firms contribute to technological upgradation, whereas innovation practices of foreign firms affect domestic technical change in indigenous firms. They use the system GMM technique with lagged values of endogenous variables as instruments. Using internal instruments or the lagged value of endogenous regressors as instrument may not give the unbiased results owing to correlation between the actual and lagged values of regressors. However, using external instruments checks for possible endogeneity and improves the credibility of results. The literature on productivity spillovers estimation by foreign firms also pictures the lack of indirect spillovers by foreign firms in indigenous firms, as earlier discussed. The validity of results is also confirmed by choosing different estimation strategies. For the static IV regression, 2SLS, extended 2SLS, and GMM are used as also LIML and CUE specifications of the model. Standard errors are consistent under homoscedasticity for both these estimators, thus reducing the biasedness of coefficients. Similarly, the choice of different instruments allows checking for different combinations of instruments and the validity of results, confirmed by different combinations of instruments. Using system GMM allows checking for possible endogeneity that may have caused biased coefficients. The robustness of results from a dynamic setting supports the validity of results. In fact, the heterogeneity at different levels also supports the increases in wage inequality caused by 
foreign firms. The effect is consistent for all sizes of firms and for older firms and regions. Hightechnology firms have a high effect of foreign share on wages as well as the interaction term, which is quite expected via the channel of training.

\subsection{Heterogeneity and other robustness checks}

Heterogeneity is explored at different levels in the present study dataset. Different levels of heterogeneity are tested in the data for static GMM using all instruments.

Results from the size group remain robust to previous regressions. Appendix Table A6 shows the results for firms belonging to different deciles. Decile 1 firms have the highest positive coefficient of 0.48 compared with firms in deciles 2 and 3, which have coefficients of 0.32 and 0.19 , respectively. The coefficient of interaction term foreign share $\times$ training is also positive for all deciles, but is significant for firms in deciles 1 and 3 .

Appendix Table A7 shows the results for the baseline model for different age groups of firms. Positive and significant coefficient of foreign share is noted for firms belonging to the age groups $>65$ and 43-30 years. The interaction term is also positive and significant for firms in the age group $>65$ years and $29-25$ years. Thus, relatively older and middle-aged firms have higher demand side effect of foreign share on relative wages.

Industry-wise results are depicted in Appendix Table A8. Firms in high- and low-technology industries are tested for separately: the former category includes metal, chemicals, machinery, and transport equipment firms, and the latter includes food, textiles, consumer goods, and construction. Results suggest that the high-technology firms show a positive and significant coefficient of foreign share (0.61). The coefficient of interaction term also remains positive and significant. However, no significant results are found for low-technology firms.

Appendix Table A9 shows the results for different regions. The states are divided into four regions: north, south, east, and west. Results show the positive effect of the interaction term in all the regions, although the effect of foreign share and training is not significant.

In further analysis, the baseline model is tested with balanced panel and results are shown in Appendix Table A10. They suggest the coefficient of foreign share remains in a similar range $(0.40-0.49)$ as static results. The coefficient of training is also positive and significant, ranging from 2.34 to 4.70 for different specifications of the models. Interestingly, the coefficient of interaction term also remains positive and significant confirming prior results.

The changes in Indian shares in firms are examined and the robustness of results is reported in Appendix Table A11. The results reveal a significant and positive coefficient of 0.67 for foreign share, suggesting a positive effect of foreign share on relative wages; this is confirmed by the interaction term foreign sharextraining. Thus, given the shares of Indian promoters in Indian firms the hypothesis of increasing wage inequality by foreign firms remains robust.

Following the literature on impact of FDI on host countries, another channel of effect of foreign share on wage inequality is explored and results are reported in Appendix Table A12. R\&D expenses of firms are taken into account. These expenses may create knowledge spillovers in the host economy, correlate with demand for skilled labour, and affect wages through this channel. No significant effects of R\&D and its interaction term are found. However, the effect of foreign share and the interaction term foreign sharextraining are still positive and significant. 
The variation in investment by firms in the study dataset is exploited by dividing the dataset into high- and low-investment groups by the median value of investment (Appendix Table A13). The results suggest a positive effect of foreign share on relative wages in high-investment firms along with a positive coefficient of interaction term foreign sharextraining, suggesting a positive relative demand effect. The effect of foreign share for low-investment firms is in the same direction as that of high-investment firms, although with a smaller magnitude. The interaction term is positive but not significant.

\section{$7 \quad$ Conclusion}

The high inflows of FDI in the Indian economy, with reduction and removal of sectoral caps in many sectors in the post-reform period (especially after 2000), provides a good background to probe into the labour market effects. Although the literature accounts for the indirect effects of FDI in host countries by different horizontal and vertical spillover channels, there is still dearth of literature on assessing this effect with the direct channel of on-the-job training specifically in India. This paper attempts to examine whether FDI has helped the Indian manufacturing sector in the period 2001-15. The paper takes into account the dynamics involved in the process and uses static and dynamic GMM to test FDI effects. It also considers decision-making on the part of foreign firms to invest as endogenous.

This study uses different tested instruments that determine FDI, including market size, infrastructure, distance from main market area, and a religion and cast fractionalization index. All these instruments have been tested properly and used by previous studies. It checks the robustness of the results by using more efficient and different methods of static GMM, and different combinations of more significant instruments.

The study fails to find any positive human capital formation effects through on-the-job training given to employees. Rather, it finds a positive demand side effect of foreign firms-led human capital formation; that is, the increase in wage inequality over time. The results also remain robust with different alterations of the models and while accounting for different levels of heterogeneity, for example: different high- and low-technology industries, age-wise, size-wise, controlling for R\&D, and Indian shares of firms. Another robustness check divided the industries on the basis of investment; the results remain robust.

Regarding the policies on effect of FDI on human capital formation in host countries, there are examples of better coordination between government and MNEs to lessen the demand and supply gap in the labour market, such as Singapore's Skill Development Fund, Malaysia's Human Resource Development Fund, and the Penang Skill Development Centre; they represent coordination between government, business, and academia in supplying skills. Although India has started the National Skill Development Corporation, which aims to create skills by establishing vocational institutes using public-private partnerships, empirical evidence suggests that there is requirement for better coordination between institutions to bridge the skill gap that may have caused these results. 


\section{References}

Agosin, M., and R. Mayer (2000). 'Foreign Investment in Developing Countries: Does It Crowd in Domestic Investment?'. UNCTAD Discussion Paper 146, February. Geneva: United Nations Conference on Trade and Development (UNCTAD). Available at: http://unctad.org/en/docs/dp_146.en.pdf (accessed 17 October 2016).

Aitken, B.J., and A.E. Harrison (1999) 'Do Domestic Firms Benefit from Direct Foreign Investment? Evidence from Venezuela'. American Economic Review, 89(3): 605-18.

Aiyar, S., and A. Mody (2011). 'The Demographic Dividend: Evidence from the Indian States'. IMF Working Paper WP/11/38. Washington, DC: International Monetary Fund (IMF). Available at: https://www.imf.org/external/pubs/ft/wp/2011/wp1138.pdf (accessed 17 October 2016).

Alfaro, L., A. Chanda, K.S. Ozcan, and S. Sayek (2004). 'FDI and Economic Growth: The Role of Local Financial Markets'. Journal of International Economics, 64(1): 89-112.

Azam, M. (2010). 'India's Increasing Skill Premium: Role of Demand and Supply'. The B.E. Journal of Economic Analysis \& Policy, 10(1): 1-28.

Ballot, G., F. Fakhfakh, and E. Taymaz (2006). 'Who Benefits from Training and R\&D, the Firm or the Workers?'. British Journal of Industrial Relations, 44: 473-95.

Baranwal, G. (2016). 'Does Foreign Direct Investment Form Human Capital? A Study with World Input-Output Data in India'. In D. Chakraborty and J. Mukherjee (eds), Trade, Investment and Economic Development in Asia: Empirical and Policy Issues. London: Routledge, Chapter 9, pp. 161-74.

Blomström, M. (1986). 'Foreign Investment and Productive Efficiency: The Case of Mexico'. Journal of Industrial Economics, 35(1): 97-110.

Blundell, R., and S. Bond (1998). 'Initial Conditions and Moment Restrictions in Dynamic Panel Data Models'. Journal of Econometrics, 87(1): 115-43.

Borensztein, E., J. Gregorio, and W. Lee (1998). 'How Does Foreign Direct Investment Affect Economic Growth?'. Journal of International Economics, 45(1): 115-35.

Caves, R. (1974). 'Multinational Firms, Competition and Productivity in the Host Country'. Economica, 41: 176-93.

Chamarbagwala, R. (2006). 'Economic Liberalization and Wage Inequality in India'. World Development, 34(12): 1997-2015.

CMIE (2016). Prowess: Largest Database of Financial Performance of Indian Companies. Centre for Monitoring Indian Economy Pvt Ltd. Available at: https://prowess.cmie.com/kommon/bin/sr.php?kall=wprowstat\&sectcode $=010$ (accessed 17 October 2016).

de Mello, Luiz R., Jr (1999). 'Foreign Direct Investment-Led Growth: Evidence from Time Series and Panel Data'. Oxford Economic Papers, 51(1): 133-51.

DIPP (2016a). SIA Newsletter, 23(18). New Delhi: Secretariat for Industrial Assistance (SIA), Department of Industrial Policy \& Promotion (DIPP), Ministry of Commerce \& Industry, Government of India. Available at: http://dipp.nic.in/English/Publications/SIA_Newsletter/2016/apr2016/index.htm (accessed 17 October). 
DIPP (2016b). Quarterly Fact Sheet: Fact Sheet on Foreign Direct Investment (FDI) from April 2000 to March 2016. New Delhi: Department of Industrial Policy \& Promotion (DIPP), Ministry of Commerce \& Industry, Government of India. Available at: http://dipp.gov.in/English/Publications/FDI_Statistics/2016/FDI_FactSheet_JanuaryFeb ruaryMarch2016.pdf (accessed 17 October).

Dua, P., B. Goldar, and R.S. Behera (2011). 'Foreign Direct Investment and Technology Spillover: An Evaluation Across Different Clusters in India'. eSocialSciences Working Papers 4382; also published as CDE Working Paper 200, August. Delhi: Centre for Development Studies (CDE), Delhi School of Economics. Available at: http://www.cdedse.org/pdf/work200.pdf (accessed 17 October 2016).

Feenstra, R.C., and G.H. Hanson (1997). 'Foreign Direct Investment and Relative Wages: Evidence from Mexico's Maquiladoras'. Journal of International Economics, 42(3-4): 371-93.

Figini, P., and H. Görg (2006). 'Does Foreign Direct Investment Affect Wage Inequality? An Empirical Investigation'. IZA Discussion Paper 2336, September. Bonn: Institute for the Study of Labor (IZA). Available at: http://www.waipa.org/wpcontent/uploads/2016/07/Figini-and-Gorg_Does-FDI-Affect-Wage-Inequality-AnEmpirical-Investigation.pdf (accessed 17 October 2016).

Fu, X., and Y. Gong (2011). 'Indigenous and Foreign Innovation Efforts and Drivers of Technological Upgrading: Evidence from China'. World Development, 39(7): 1213-25.

Ghosh, S. (2016). 'Estimating the Demographic Dividend: Evidence from Indian States'. Journal of Population Ageing, 9(3): 249-63.

Girma, S., and H. Görg (2005). 'Foreign Direct Investment, Spillovers and Absorptive Capacity: Evidence from Quantile Regressions'. Discussion Paper Series 1: Economic Studies 13/2005. Frankfurt: Deutsche Bundesbank. Available at: https://www.bundesbank.de/Redaktion/EN/Downloads/Publications/Discussion_Paper _1/2005/2005_05_06_dkp_13.pdf?_blob=publicationFile (accessed 17 October 2016).

Gisselquist, M.R., S. Leiderer, and N.M. Zarazúa (2016). 'Ethnic Heterogeneity and Public Goods Provision in Zambia: Evidence of a Subnational "Diversity Dividend" '. World Development, 78: 308-23.

Haddad, M., and A. Harrison (1993). 'Are There Positive Spillovers from Direct Foreign Investment?'. Journal of Development Economics, 42(1): 51-74.

Hasan R., D. Mitra, and K.V. Ramaswamy (2007). 'Trade Reforms, Labor Regulations, and Labor-Demand Elasticities: Empirical Evidence from India'. Review of Economics and Statistics, 89(3): 466-81.

Javorcik, S.B. (2004) 'Does Foreign Direct Investment Increase the Productivity of Domestic Firms? In Search of Spillovers Through Backward Linkages'. American Economic Review, 94(3): 605-27.

Keller W., and S. Yeaple (2009). 'Multinational Enterprises, International Trade, and Technology Diffusion: A Firm-Level Analysis of the Productivity Effects of Foreign Competition in the United States'. Review of Economics and Statistics, 91(4): 821-31.

Kapstein, E.B. (2002). 'Virtuous Circles? Human Capital Formation, Economic Development and the Multinational Enterprise'. OECD Working Paper 191 (formerly Technical Paper 191), August. Paris: OECD Development Centre. Available at: http://www.oecd.org/dev/1949106.pdf (accessed 17 October 2016). 
Kathuria, V. (2001). 'Foreign Firms, Technology Transfer and Knowledge Spillovers to Indian Manufacturing Firms: A Stochastic Frontier Analysis'. Applied Economics, 33(5): 625-42.

Katz, L.F. and K.M. Murphy (1992). 'Changes in Relative Wages, 1963-1987: Supply and Demand Factors'. The Quarterly Journal of Economics, 107(1): 35-78.

Labour Bureau (2012-13). 'Wage Rates in Rural India, 2012-13'. Shimla: Ministry of Labour \& Employment, Government of India. Available at: http://labourbureau.gov.in/WRRI_2014_Report.pdf (accessed 17 October 2016).

MHRD (2014). 'Educational Statistics at a Glance'. New Delhi: Ministry of Human Resource Development (MHRD), Bureau of Planning, Monitoring \& Statistics, Government of India. Available at: http://mhrd.gov.in/sites/upload_files/mhrd/files/statistics/EAG2014.pdf (accessed 17 October 2016).

MHRD (2016). 'All India Survey on Higher Education, 2014-15'. New Delhi: Ministry of Human Resource Development (MHRD), Bureau of Planning, Monitoring \& Statistics, Government of India. Available at: http://mhrd.gov.in/sites/upload_files/mhrd/files/statistics/AISHE\%202014-15F.pdf (accessed 17 October 2016).

Markusen, J. (1995). 'The Boundaries of Multinational Enterprises and the Theory of International Trade'. Journal of Economic Perspectives, 9: 169-89.

Narula, R., and A. Marin (2005). 'Foreign Direct Investment Spillovers, Absorptive Capacities and Human Capital Development: Evidence from Argentina'. ILO Working Paper 96. Geneva: International Labour Organization (ILO). Available at: http://www.ilo.org/public/libdoc/ilo/2005/105B09_209_engl.pdf (accessed 3 November 2016).

Noorbakhsh, F., A. Paloni, and A. Youssef (2001). 'Human capital and FDI inflows to developing countries: New empirical evidence'. World Development, 29(9): 1593-610.

Nunnenkamp, P., and M. Mukim (2011). 'The Clustering of FDI in India: The Importance of Peer Effects'. Kiel Working Papers 1697, May. Germany: Kiel Institute for the World Economy. Available at: https://www.ifw-members.ifw-kiel.de/publications/the-clusteringof-fdi-in-india-the-importance-of-peer-effects/kwp-1697.pdf (accessed 3 November 2016).

Pflueger, E.C., and S. Wang (2015). 'A Robust Test for Weak Instruments in Stata'. The Stata Journal, 15(1): 216-25.

Ramaswamy, K.V. (2008). 'Wage Inequality in Indian Manufacturing: Is It Trade, Technology or Labour Regulations?'. Labour Economics Working Paper 22361. East Asian Bureau of Economic Research. Available at: http://www.eaber.org/node/22361 (accessed 17 October 2016).

Reserve Bank of India (2015). 'Frequently Asked Questions: Foreign Investments in India' [updated 10 February 2015]. Available at: https://www.rbi.org.in/scripts/FAQView.aspx?Id=26 (accessed 17 October 2016).

Reserve Bank of India (n.d.). 'Average Daily Wage Rates (in Rs.) in Rural India for Men'. Database on Indian Economy. Available at: https://dbie.rbi.org.in/DBIE/dbie.rbi?site=statistics (accessed 17 October 2016).

Ritchie, B.K. (2002). 'Foreign Direct Investment and Intellectual Capital Formation in Southeast Asia'. OECD Working Paper 194 (formerly Technical Paper 194), August. Paris: OECD Development Centre. Available at: http://www.oecd.org/dev/1949901.pdf (accessed 17 October 2016). 
Sasidharan, S., and V. Kathuria (2011). 'Foreign Direct Investment and R\&D: Substitutes or Complements-A Case of Indian Manufacturing After 1991 Reforms'. World Development, 39(7): 1226-39.

Slaughter, M.J. (2002). 'Skill Upgrading in Developing Countries: Has Inward Foreign Direct Investment Played a Role?'. OECD Working Paper 192 (formerly Technical Paper 192), August. Paris: OECD Development Centre. Available at: http://www.oecd.org/dev/1949135.pdf (accessed 17 October 2016).

Stock, J.H., and M. Yogo (2002). 'Testing for Weak Instruments in Linear IV Regression'. NBER Technical Working Paper 0284, October. Cambridge, MA: National Bureau of Economic Research. Available at: http://www.nber.org/papers/t0284.pdf (accessed 3 November 2016).

Tan, H., and G. Batra (1997). 'Technology and Firm Size-Wage Differentials in Colombia, Mexico, and Taiwan (China)'. World Bank Economic Review, 11(1): 59-83.

Te Velde, D.W. (2001). 'Foreign Direct Investment and Factor Prices in U.S. Manufacturing'. Review of World Economics, 137(4): 622-43.

Te Velde, D.W., and O. Morrissey (2004). 'Foreign Direct Investment, Skills and Wage Inequality in East Asia'. Journal of the Asia Pacific Economy, 9(3): 348-69. 


\section{Appendix A: Definitions and static-dynamic results}

\section{A1 Definition of variables}

- $\{r l w\}_{i t}=\left\{w_{S i t} / w_{U i t}\right\}$ : relative price of labour, ratio of skilled and unskilled labour force in firms.

- $F S_{i t}$ : equity shares held by foreign promoters in the firm.

- $\operatorname{train}_{i r}$ annual on-the-job training expenses of firms.

- size $e_{i t}$ annual sales of the firms.

- $F S_{i t} \times \operatorname{train}_{i t}$ interaction term of equity shares and training expenses of firms.

\section{A2 Definition of instruments (state-wise)}

- Size of main market: log of population.

- Distance from main market area: log of distance from main market area in kilometres.

- Length of national highways: log of length of national highways in kilometres.

- Availability of non-agricultural land: $\log$ of available non-agricultural land.

- Fractionalization index $(F I)=\sum_{g=1}^{n} q_{g i}^{2}$, where $g$ is population share of caste or religious group.

- Foreign direct investment (FDI): proxy for measuring FDI is foreign equity in annual equity shares of firms. It is a continuous variable ranging from 0 to 100.

- On-the-job training: measure of annual expenses financed by firms on training their employees (which upgrades the level of skills). This term is normalized by dividing it by sales of firms.

- FDI train: interaction term of foreign equity shares and on-the-job training expenses of firms.

- Size: total annual sales of the firms; it controls for firm-specific characteristics.

- Size $e^{2}$ : term that accounts for the non-linarites in firm-specific indicators. 
Table A1: Static IV results, relative wages (rural) dependent variable (all instruments)

\begin{tabular}{|c|c|c|c|c|c|}
\hline Explanatory variables & $\begin{array}{c}\text { 2SLS } \\
(1)\end{array}$ & $\begin{array}{c}\text { GMM } \\
(2) \\
\end{array}$ & $\begin{array}{c}\text { LIML } \\
(3)\end{array}$ & $\begin{array}{c}\text { ExIV2SLS } \\
(4)\end{array}$ & $\begin{array}{c}\text { CUE } \\
(5) \\
\end{array}$ \\
\hline Foreign share & $0.41^{\text {*t" }}(0.12)$ & $0.36^{4 x}(0.11)$ & $0.72^{2 x}(0.20)$ & $0.41^{\text {*1" }}(0.12)$ & $0.45^{\text {kxx }}(0.11)$ \\
\hline Training & $0.02(0.01)$ & $0.01(0.01)$ & $0.03(0.01)$ & $0.02(0.01)$ & $0.01^{\star \star \star}(0.01)$ \\
\hline Foreign share $\times$ Training & $0.001^{\star \star \star}(0.00001)$ & $0.001^{\star \star \star}(0.0001)$ & $\begin{array}{l}0.0009^{* \star \pi \times} \\
(0.00001)\end{array}$ & $0.001^{\star \star \star}(0.0001)$ & $0.001^{\star \star \star}(0.0001)$ \\
\hline Size & $0.003^{\star \star \star}(0.00005)$ & $0.0003^{\star \star \star}(0.0004)$ & $0.0008(0.00005)$ & $0.0003^{\star \star \star}(0.0005)$ & $0.0003^{\star \star \star}(0.00005)$ \\
\hline $\operatorname{Size}^{2}$ & $-3.85 e-09(4.66 e-100)$ & $-3.54 \mathrm{e}-09^{\star \star \star}(4.25 \mathrm{e}-10)$ & - & $-3.85 \mathrm{e}-09^{\star \star \star}(4.66 \mathrm{e}-10)$ & $-3.60 \mathrm{e}-09^{\star \star \star}(4.38 \mathrm{e}-10)$ \\
\hline$R^{2}$ & 0.64 & 0.66 & 0.33 & 0.72 & 0.66 \\
\hline Montiel-Pflueger robust weak instrument test & 7.332 & 7.332 & 7.399 & - & - \\
\hline Kleibergen-Paap rk LM statistic & & & & 34.818 & 34.818 \\
\hline Cragg-Donald Wald F statistic & & & & 5.946 & 5.946 \\
\hline Kleibergen-Paap $r k$ Wald F statistic & & & & 7.762 & 7.762 \\
\hline Constant & $-26.11^{\star \star \star}(7.22)$ & $-23.07^{\star \star \star}(6.56)$ & $-43.53^{\star \star \star}(12.08)$ & $-26.11^{\star \star \star}(7.22)$ & $-28.83^{* \star \star}(7.08)$ \\
\hline$N$ & 1376 & 1376 & 1376 & 1376 & 1376 \\
\hline
\end{tabular}

Note: Robust standard errors are in parentheses. All specifications include full set of time and two-digit level industry dummies. *, ${ }^{*}$, and $* \star *$ indicate levels of significance at 10,5 , and 1 per cent.

Source: Author's compilation based on study dataset.

Table A2: Static IV results, relative wages (rural) dependent variable (log of population + distance from main market area + fractionalization)

\begin{tabular}{|c|c|c|c|c|c|}
\hline Explanatory variables & $\begin{array}{l}2 S L S \\
(1)\end{array}$ & $\begin{array}{l}\text { GMM } \\
\text { (2) }\end{array}$ & $\begin{array}{l}\text { LIML } \\
\text { (3) }\end{array}$ & $\begin{array}{c}\text { ExIV2SLS } \\
\text { (4) }\end{array}$ & $\begin{array}{l}\text { CUE } \\
(5)\end{array}$ \\
\hline Foreign share & $0.85^{\text {*ै }}(0.25)$ & $0.75^{\text {रे }}(0.21)$ & $0.92^{\text {kरे }}(0.28)$ & $0.85^{\text {रे }}(0.25)$ & $0.85^{\text {रे }}(0.23)$ \\
\hline Training & $0.04^{*}(0.02)$ & $0.03(0.02)$ & $0.05^{\star}(0.02)$ & $0.04^{*}(0.02)$ & $0.04^{*}(0.02)$ \\
\hline Foreign share $\times$ Training & $0.0008^{\star \star \star}(0.00001)$ & $0.0009^{\star \star \star}(0.00001)$ & $0.0008^{* \star \star}(0.0001)$ & $0.0008^{* \star \star}(0.00001)$ & $0.001^{\star \star \star}(0.0004)$ \\
\hline Size & $0.0001^{\star \star \star}(0.00006)$ & $0.0001^{\star \star \star}(0.00006)$ & $0.0001^{*}(0.00002)$ & $0.0001^{\star \star \star}(0.00006)$ & $0.0008^{\star \star \star}(0.0001)$ \\
\hline $\mathrm{Size}^{2}$ & $4.36 \mathrm{e}-11(1.94 \mathrm{e}-10)$ & $5.98 \mathrm{e}-11(1.96 \mathrm{e}-10)$ & - & $4.36 \mathrm{e}-11(1.94 \mathrm{e}-10)$ & $-4.67 \mathrm{e}-11^{\star \star \star}(1.97 \mathrm{e}-10)$ \\
\hline$R^{2}$ & 0.65 & 0.43 & 0.48 & 0.65 & 0.41 \\
\hline Montiel-Pflueger robust weak instrument test & 7.264 & 7.281 & 7.264 & & \\
\hline Kleibergen-Paap rk LM statistic & & & & 19.731 & 19.731 \\
\hline Cragg-Donald Wald F statistic & & & & 4.800 & 4.800 \\
\hline Kleibergen-Paap $r k$ Wald F statistic & & & & 8.26 & 8.26 \\
\hline Constant & $-44.61^{* \star}(12.82)$ & $-44.61^{* *}(12.82)$ & $-54.85^{\star \star}(16.63)$ & $-51.05^{* *}(14.83)$ & $-50.68^{\star \star \star}(13.81)$ \\
\hline$N$ & 1608 & 1608 & 1608 & 1608 & 1608 \\
\hline
\end{tabular}

Note: Robust standard errors are in parentheses. All specifications include full set of time and two-digit level industry dummies. ${ }^{*}$ * , and ${ }^{* \star}$ indicate levels of significance at 10,5 , and 1 per cent.

Source: Author's compilation based on study dataset. 
Table A3: Static IV results, relative wages (industrial) dependent variable (all instruments)

\begin{tabular}{|c|c|c|c|c|c|}
\hline Explanatory variables & $\begin{array}{c}2 \text { 2SLS } \\
(1)\end{array}$ & $\begin{array}{c}\text { GMM } \\
(2) \\
\end{array}$ & $\begin{array}{c}\text { LIML } \\
\text { (3) }\end{array}$ & $\begin{array}{c}\text { ExIV2SLS } \\
(4)\end{array}$ & $\begin{array}{c}\text { CUE } \\
(5)\end{array}$ \\
\hline Foreign share & $0.27^{\text {kxt }}(0.11)$ & $0.27^{\text {knt }}(0.08)$ & $0.17(0.11)$ & $0.27^{\text {सेर }}(0.18)$ & $0.25^{n+1}(0.09)$ \\
\hline Training & $-0.008(0.01)$ & $-0.01(0.01)$ & $-0.02(0.01)$ & $-0.008(0.01)$ & $-0.01(0.01)$ \\
\hline Foreign share $\times$ Training & $0.0002^{\star \star}(0.00007)$ & $0.001^{\star \star \star}(0.0004)$ & $0.003^{\star \star \star}(0.0008)$ & $0.0002^{* \star}(0.00007)$ & $0.0002^{\star \star \star}(0.00007)$ \\
\hline Size & $0.0001^{\star \star \star}(0.00001)$ & $0.0001^{\star \star \star}(0.00001)$ & $0.0004^{\star *}(0.00001)$ & $0.0001^{\star \star \star}(0.00001)$ & $0.001^{\star \star \star}(0.0001)$ \\
\hline $\operatorname{Size}^{2}$ & $-1.67 \mathrm{e}-10^{* *}(2.59 \mathrm{e}-11)$ & $-1.57 \mathrm{e}-10^{\star \star \star}(2.43 \mathrm{e}-11)$ & - & $-1.67 e-10^{\star *}(2.59 \mathrm{e}-11)$ & $-1.59 \mathrm{e}-10^{\star \star \star}(2.45 \mathrm{e}-11)$ \\
\hline$R^{2}$ & 0.61 & 0.62 & 0.54 & 0.66 & 0.53 \\
\hline Montiel-Pflueger robust weak instrument test & 8.808 & 8.808 & 8.829 & & \\
\hline Kleibergen-Paap rk LM statistic & & & & 39.811 & 39.811 \\
\hline Cragg-Donald Wald F statistic & & & & 6.890 & 6.890 \\
\hline Kleibergen-Paap $r k$ Wald F statistic & & & & 8.405 & 8.405 \\
\hline Constant & $-14.56^{*}(6.46)$ & $-11.18(5.25)$ & $-8.16(6.83)$ & $-14.56^{\star}(6.46)$ & $-13.34^{* *}(5.44)$ \\
\hline$N$ & 1788 & 1788 & 1788 & 1788 & 1788 \\
\hline
\end{tabular}

Note: Robust standard errors are in parentheses. All specifications include full set of time and two-digit level industry dummies. *, **, and ${ }^{* \star *}$ indicate levels of significance at 10,5 , and 1 per cent.

Source: Author's compilation based on study dataset.

Table A4: Static IV results, relative wages (industrial) dependent variable (log of population + distance from main market area + fractionalization)

\begin{tabular}{|c|c|c|c|c|c|}
\hline Explanatory variables & $\begin{array}{l}\text { 2SLS } \\
(1)\end{array}$ & $\begin{array}{l}\text { GMM } \\
(2)\end{array}$ & $\begin{array}{l}\text { LIML } \\
\text { (3) }\end{array}$ & $\begin{array}{c}\text { ExIV2SLS } \\
(4)\end{array}$ & $\begin{array}{c}\text { CUE } \\
(5)\end{array}$ \\
\hline Foreign share & $0.43^{\text {*x }}(0.18)$ & $0.41^{\text {*x }}(0.18)$ & $0.43^{\text {** }}(0.23)$ & $0.43^{\text {*x }}(0.18)$ & $0.46^{* x}(0.18)$ \\
\hline Training & $-0.007(0.01)$ & $0.005(0.01)$ & $0.002^{*}(0.01)$ & $0.007(0.01)$ & $0.009(0.01)$ \\
\hline Foreign share $\times$ Training & $0.0001^{\star \star}(0.00001)$ & $0.002^{\star \star \star}(0.0006)$ & $0.0004^{\star \star \star}(0.0001)$ & $0.0002^{\star \star}(0.00007)$ & $0.0002^{\star \star \star}(0.00006)$ \\
\hline Size & $0.0001^{\star \star \star}(0.00001)$ & $0.0001^{\star \star \star}(0.00001)$ & $0.0003^{\star \star}(0.00007)$ & $0.0001^{\star \star \star}(0.00002)$ & $0.001^{\star \star \star}(0.0001)$ \\
\hline $\operatorname{Size}^{2}$ & $-1.59 \mathrm{e}-10^{\star \star}(2.35 \mathrm{e}-11)$ & $-1.57 \mathrm{e}-10^{\star \star \star}(2.33 \mathrm{e}-11)$ & - & $-1.59 \mathrm{e}-10^{\star \star}(2.35 \mathrm{e}-11)$ & $-1.60 \mathrm{e}-10^{\star \star \star}(2.35 \mathrm{e}-11)$ \\
\hline$R^{2}$ & 0.51 & 0.52 & 0.43 & 0.61 & 0.53 \\
\hline Montiel-Pflueger robust weak instrument test & 6.213 & 6.83 & 6.244 & & \\
\hline Kleibergen-Paap rk LM statistic & & & & 20.808 & 20.808 \\
\hline Cragg-Donald Wald F statistic & & & & 4.133 & 4.133 \\
\hline Kleibergen-Paap $r k$ Wald F statistic & & & & 7.543 & 7.543 \\
\hline Constant & $-23.38^{*}(10.68)$ & $-22.19(10.44)$ & $-23.00^{*}(13.43)$ & $-23.38^{*}(10.68)$ & $-25.32^{*}(10.83)$ \\
\hline$N$ & 2096 & 2096 & 2096 & 2096 & 2096 \\
\hline
\end{tabular}

Note: Robust standard errors are in parentheses. All specifications include full set of time and two-digit level industry dummies. ${ }^{\star},{ }^{*}$, and ${ }^{\star \star \star}$ indicate levels of significance at 10,5 , and 1 per cent.

Source: Author's compilation based on study dataset. 
Table A5: Dynamic system GMM results, relative wages (rural and industrial) dependent variable

\begin{tabular}{|c|c|c|c|c|}
\hline Explanatory variables & $\begin{array}{c}(1)^{a 1}(a l l) \\
\text { Rural wages }\end{array}$ & $\begin{array}{c}\left.(2)^{b 1} \text { (population }+ \text { distance }+ \text { fractionalization }\right) \\
\text { Rural wages }\end{array}$ & $\begin{array}{c}(3)^{\mathrm{a} 1}(\mathrm{all}) \\
\text { Industrial wages }\end{array}$ & $\begin{array}{c}\left.(4)^{b 1} \text { (population + distance + fractionalization }\right) \\
\text { Industrial wages }\end{array}$ \\
\hline Relative wages & $0.92^{x}(0.42)$ & $0.95^{*}(0.24)$ & $1.13^{x \times x}(0.16)$ & $1.50^{\text {k.xx }}(0.33)$ \\
\hline Foreign share & $0.20^{\star \star \star x}(0.04)$ & $0.19^{\text {*xt }}(0.0)$ & $0.03(0.02)$ & $0.001(0.008)$ \\
\hline Training & $-1.37(0.59)$ & $2.42^{\star \star \star}(0.60)$ & $1.56(0.94)$ & $0.84(0.64)$ \\
\hline Foreign share $x$ Training & $0.0003^{\star *}(0.0001)$ & $0.0003^{\star \star}(0.0001)$ & $0.0003^{\star *}(0.0001)$ & $0.0008^{\star \star}(0.0004)$ \\
\hline Size & $0.0003(0.00002)$ & $0.0002(0.0002)$ & $0.0003(0.0007)$ & $0.0007(0.0007)$ \\
\hline$A R(1)$ & $-1.82(0.06)$ & $-1.82(0.06)$ & $-1.70(0.08)$ & $-1.80(0.07)$ \\
\hline$A R(2)$ & $-1.14(0.25)$ & $-1.14(0.25)$ & $-1.29(0.29)$ & $0.39(0.69)$ \\
\hline Sargan test ( $P$ value) & $(0.93)$ & $(0.93)$ & $(0.85)$ & $(0.59)$ \\
\hline Instruments & 54 & 51 & 31 & 29 \\
\hline N & 867 & 867 & 993 & 999 \\
\hline
\end{tabular}

Note: Robust standard errors are in parentheses. All specifications include full set of time and two-digit level industry dummies. ${ }^{*}$ **, and ${ }^{* *}$ indicate levels of significance at 10, 5, and 1 per cent.

Source: Author's compilation based on study dataset.

Table A6: Static IV results, relative wages (rural) dependent variable (all instruments), size-wise heterogeneity

\begin{tabular}{|c|c|c|c|}
\hline Explanatory variables & $\begin{array}{c}\text { Decile } 1 \\
\text { (1) }\end{array}$ & $\begin{array}{c}\text { Decile } 2 \\
(2)\end{array}$ & $\begin{array}{c}\text { Decile } 3 \\
(3)\end{array}$ \\
\hline Foreign share & $0.48^{\text {*x }}(0.18)$ & $0.32^{*}(0.19)$ & $0.19^{\text {xखे }}(0.08)$ \\
\hline Training & $0.01(0.03)$ & $5.27^{*}(3.63)$ & $5.47(8.51)$ \\
\hline Foreign share $\times$ Training & $0.001^{\star \star \star}(0.0002)$ & $0.0004(0.0008)$ & $0.002^{* \star \star *}(0.001)$ \\
\hline Size & $0.0004^{* \star \star}(0.00008)$ & $0.002^{\star \star \star}(0.0009)$ & $0.0003^{* \star}(0.0001)$ \\
\hline Size & $-4.63 e-09^{\star \star \star}(5.71 e-10)$ & $2.58 \mathrm{e}-11^{\star \star}(2.40 \mathrm{e}-10)$ & $6.12 \mathrm{e}-09^{\star \star \star}(1.39 \mathrm{e}-08)$ \\
\hline$R^{2}$ & 0.73 & 0.84 & 0.78 \\
\hline Constant & $-31.23^{\star \star \star}(11.38)$ & $-18.52^{\star}(10.64)$ & $-10.97^{\star \star}(4.56)$ \\
\hline Kleibergen-Paap rk LM statistic & 24.003 & 6.945 & 12.223 \\
\hline Cragg-Donald Wald F statistic & 6.665 & 1.388 & 5.233 \\
\hline Kleibergen-Paap $r k$ Wald $F$ statistic & 7.963 & 3.198 & 7.966 \\
\hline$N$ & 762 & 620 & 226 \\
\hline
\end{tabular}

Note: Robust standard errors are in parentheses. All specifications include full set of time and two-digit level industry dummies. *, $* \star$, and ${ }^{\star \star \star}$ indicate levels of significance at 10,5 , and 1 per cent.

Source: Author's compilation based on study dataset. 
Table A7: Static IV results, relative wages (rural) dependent variable (all instruments), age-wise heterogeneity

\begin{tabular}{|c|c|c|c|c|c|}
\hline Explanatory variables & $\begin{array}{c}>65 \text { years } \\
\text { (1) }\end{array}$ & $\begin{array}{c}\text { 65-44 years } \\
\text { (2) }\end{array}$ & $\begin{array}{c}\text { 43-30 years } \\
(3)\end{array}$ & $\begin{array}{c}29-25 \text { years } \\
(4)\end{array}$ & $\begin{array}{c}<24 \text { years } \\
(5)\end{array}$ \\
\hline Foreign share & $0.30^{\text {xix }}(0.10)$ & $-0.06(0.24)$ & $0.01^{*}(0.006)$ & $0.09(0.06)$ & $-0.03(0.09)$ \\
\hline Training & $1.61(2.37)$ & $-3.61(1.52)$ & $0.005^{*}(0.002)$ & $0.008(0.009)$ & $59.21(26.07)$ \\
\hline Foreign share $\times$ Training & $0.001^{\star \star *}(0.0001)$ & $0.001^{\star \star *}(0.0002)$ & $0.0001(0.0002)$ & $0.006^{\star \star \star}(0.0001)$ & $0.008(0.003)$ \\
\hline Size & $0.003^{* * \star}(0.0005)$ & $0.0002^{* * \star}(0.0007)$ & $0.0005(0.0006)$ & $0.0006^{* \star \star}(0.00005)$ & $0.0006^{\star \star \star *}(0.0001)$ \\
\hline Size $^{2}$ & $-6.80 e-09^{\star \star \star x}(1.23 e-09)$ & $-4.55 \mathrm{e}-09^{\star \star \star}(8.76 \mathrm{e}-10)$ & $-1.46 \mathrm{e}-08^{* \star}(4.68 \mathrm{e}-09)$ & $-2.20 \mathrm{e}-08(3.63 \mathrm{e}-09)$ & $-8.36 \mathrm{e}-09^{\star \star \star \star}(2.01 \mathrm{e}-09)$ \\
\hline Constant & $-0.41(6.05)$ & $-16.02^{* \star}(5.47)$ & $0.87(14.72)$ & $-9.56(5.98)$ & $-0.415(6.05)$ \\
\hline Kleibergen-Paap rk LM statistic & 11.556 & 13.969 & 10.228 & 25.560 & 11.252 \\
\hline Cragg-Donald Wald F statistic & 5.202 & 2.495 & 2.427 & 8.612 & 1.524 \\
\hline Kleibergen-Paap $r k$ Wald $F$ statistic & 4.753 & 3.773 & 2.46 & 15.152 & 3.776 \\
\hline$N$ & 317 & 538 & 191 & 230 & 205 \\
\hline
\end{tabular}

Note: Robust standard errors are in parentheses. All specifications include full set of time and two-digit level industry dummies. *, **, and ${ }^{* * *}$ indicate levels of significance at 10,5 , and 1 per cent.

Source: Author's compilation based on study dataset.

Table A8: Static IV results, relative wages (rural) dependent variable (all instruments), industry-wise heterogeneity

\begin{tabular}{|c|c|c|c|c|c|c|c|c|c|}
\hline Industries & Foreign share & Training & $\begin{array}{c}\text { Foreign } \\
\text { share } x \text { Training }\end{array}$ & Size & $\operatorname{Size}^{2}$ & $\begin{array}{l}\text { Kleibergen } \\
\text {-Paap rk } \\
\text { LM statistic }\end{array}$ & $\begin{array}{l}\text { Cragg- } \\
\text { Donald } \\
\text { Wald } F \\
\text { statistic }\end{array}$ & $\begin{array}{l}\text { Kleibergen- } \\
\text { Paap rk } \\
\text { Wald F } \\
\text { statistic }\end{array}$ & $N$ \\
\hline $\begin{array}{l}\text { High-technology } \\
\text { industries } \\
\text { (chemicals, metal, } \\
\text { machinery and } \\
\text { transport } \\
\text { equipment) }\end{array}$ & $0.61^{\star \star \star}(0.20)$ & $-2.01(1.64)$ & $0.009^{\star \star \star}(0.0002)$ & $0.001^{\star \star \star}(0.0001)$ & $-1.94 \mathrm{e}-11^{\star \star \star}(3.60 \mathrm{e}-10)$ & 25.310 & 6.282 & 10.439 & 1163 \\
\hline $\begin{array}{l}\text { Low-technology } \\
\text { industries (food, } \\
\text { textiles, construction } \\
\text { and consumer } \\
\text { goods) }\end{array}$ & $0.16(0.12)$ & $0.003(0.001)$ & $0.0003(0.0002)$ & $0.004^{\star \star \star}(0.006)$ & $-6.42 \mathrm{e}-09^{\star \star \star}(1.21 \mathrm{e}-09)$ & 9.964 & 2.200 & 4.855 & 445 \\
\hline
\end{tabular}

Note: Robust standard errors are in parentheses. All specifications include full set of time and two-digit level industry dummies. *, ${ }^{*}$, and ${ }^{\star * *}$ indicate levels of significance at 10,5 , and 1 per cent.

Source: Author's compilation based on study dataset. 
Table A9: Static IV results, relative wages (rural) dependent variable (all instruments), state-wise heterogeneity

\begin{tabular}{|c|c|c|c|c|c|c|c|c|c|}
\hline States & Foreign share & Training & $\begin{array}{c}\text { Foreign } \\
\text { share } \times \text { Training }\end{array}$ & Size & $\operatorname{Size}^{2}$ & $\begin{array}{l}\text { Kleibergen } \\
\text {-Paap } r k \\
\text { LM statistic }\end{array}$ & $\begin{array}{l}\text { Cragg- } \\
\text { Donald Wald } \\
\text { F statistic }\end{array}$ & $\begin{array}{l}\text { Kleibergen- } \\
\text { Paap rk Wald } \\
\text { F statistic }\end{array}$ & $N$ \\
\hline North & $0.26(0.20)$ & $-0.53(0.38)$ & $0.001^{\text {*x }}(0.007)$ & $0.0001^{1 *}(0.00001)$ & $-1.49 \mathrm{e}-10^{\star \star \star}(2.90 \mathrm{e}-11)$ & 14.083 & 3.503 & 5.131 & 434 \\
\hline South & $0.04(0.09)$ & $22.83^{*}(12.40)$ & $0.001^{* \star}(0.005)$ & $0.0005^{\star \star}(0.0008)$ & $-5.64 \mathrm{e}-09^{\star \star \star}(1.42 \mathrm{e}-08)$ & 8.115 & 4.028 & 4.279 & 369 \\
\hline East & $0.04(0.04)$ & $0.35(3.25)$ & $0.001^{* \star * \pi}(0.0006)$ & $0.006^{\star \star}(0.0001)$ & $-1.40 e-08^{\star \star \star}(6.68 \mathrm{e}-09)$ & 8.970 & 4.788 & 10.125 & 176 \\
\hline West & $0.07(0.13)$ & $0.001(0.01)$ & $0.003^{*}(0.002)$ & $0.0003^{*}(0.00007)$ & $-3.39 \mathrm{e}-10^{\star \star \star}(2.34 \mathrm{e}-10)$ & 9.350 & 3.828 & 6.552 & 771 \\
\hline
\end{tabular}

Note: 'North' includes New Delhi, Bihar, Chandigarh, Haryana, Himachal Pradesh, Punjab, Uttar Pradesh, and Uttarakhand; 'South' includes Andhra Pradesh, Karnataka,

Kerala, Tamilandu, Telangana, and Pondicherry; 'East' includes Assam, West Bengal, and Orissa. 'West' includes Gujarat, Maharashtra, Rajasthan, Dadra and Nagar Haveli,

Daman and Diu, and Goa. Robust standard errors are in parentheses. All specifications include full set of time and two-digit level industry dummies. *, **, and ${ }^{\star \star \star}$ indicate levels of significance at 10, 5, and 1 per cent.

Source: Author's compilation based on study dataset.

Table A10: Static IV results, relative wages (rural) dependent variable (all instruments), balanced panel results

\begin{tabular}{|c|c|c|c|c|c|}
\hline Explanatory variables & $\begin{array}{l}\text { 2SLS } \\
\text { (1) }\end{array}$ & $\begin{array}{l}\text { GMM } \\
\text { (2) }\end{array}$ & $\begin{array}{l}\text { LIML } \\
\text { (3) }\end{array}$ & $\begin{array}{c}\text { ExIV2SLS } \\
(4)\end{array}$ & $\begin{array}{l}\text { CUE } \\
(5)\end{array}$ \\
\hline Foreign share & $0.44^{\text {**x }}(0.09)$ & $0.41^{* 2 x}(0.08)$ & $0.48^{\text {*x }}(0.15)$ & $0.40^{\text {*kx }}(0.09)$ & $0.49^{\text {*kx }}(0.10)$ \\
\hline Training & $3.89^{*}(2.55)$ & $3.53^{*}(2.39)$ & $2.34(4.96)$ & $3.05(2.48)$ & $4.70^{* \star}(2.65)$ \\
\hline Foreign share $\times$ Training & $0.0009^{* \star \star}(0.00001)$ & $0.001^{\star \star \star}(0.0001)$ & $0.001^{\star \star \star}(0.00008)$ & $0.009^{\star \star \star}(0.0001)$ & $0.0009^{\star \star \star}(0.0001)$ \\
\hline Size & $0.003^{* \star \star}(0.00005)$ & $0.0001^{\star \star \star}(0.0004)$ & $0.001^{\star \star \star}(0.00001)$ & $0.0002^{\star \star \star}(0.0004)$ & $0.0001^{\star \star \star}(0.00004)$ \\
\hline $\operatorname{Size}^{2}$ & $-3.91 \mathrm{e}-09^{\star \star \star \star}(1.05 \mathrm{e}-09)$ & $-3.83 e-09^{\star \star \star}(1.01 \mathrm{e}-09)$ & - & $-4.02 \mathrm{e}-09^{\star \star \star}(1.07 \mathrm{e}-09)$ & $-3.60 \mathrm{e}-09^{\star \star \star}(1.09 \mathrm{e}-09)$ \\
\hline$R^{2}$ & 0.40 & 0.44 & 0.30 & 0.60 & 0.49 \\
\hline Montiel-Pflueger robust weak instrument test & 5.518 & 5.518 & 4.043 & - & - \\
\hline Kleibergen-Paap rk LM statistic & & & & 23.277 & 23.277 \\
\hline Cragg-Donald Wald F statistic & & & & 4.307 & 4.307 \\
\hline Kleibergen-Paap rk Wald F statistic & & & & 5.007 & 5.007 \\
\hline Constant & $-22.32^{\star \star \star}(4.91)$ & $-20.91^{\star \star \star}(4.47)$ & $-24.02^{\star *}(8.02)$ & $-20.67^{\star \star \star}(4.84)$ & $-25.5158(5.35)$ \\
\hline$N$ & 503 & 503 & 503 & 503 & 503 \\
\hline
\end{tabular}

Note: Robust standard errors are in parentheses. All specifications include full set of time and two-digit level industry dummies. ${ }^{*},{ }^{\star \star}$, and ${ }^{\star \star \star}$ indicate levels of significance at 10,5 , and 1 per cent.

Source: Author's compilation based on study dataset. 
Table A11: Static IV results, relative wages (rural) dependent variable (all instruments), controlling for Indian shares

\begin{tabular}{lc}
\hline Explanatory variables & $(1)$ \\
\hline Foreign share & $0.67^{* \star}(0.17)$ \\
Training & $0.03^{* *}(0.01)$ \\
Foreign sharexTraining & $0.001^{* \star \star}(0.0002)$ \\
Indian share & $0.03^{*}(0.01)$ \\
Size & $-0.006^{* \star \star}(0.00006)$ \\
Size & $-9.58 \mathrm{e}-09^{* \star \star}(2.01 \mathrm{e}-09)$ \\
$R^{2}$ & 0.55 \\
Kleibergen-Paap rk LM statistic & 22.089 \\
Cragg-Donald Wald F statistic & 3.825 \\
Kleibergen-Paap rk Wald F statistic & 4.797 \\
Constant & $-37.4716^{* \star *}(9.32)$ \\
$N$ & 1145 \\
\hline
\end{tabular}

Note: Robust standard errors are in parentheses. All specifications include full set of time and two-digit level industry dummies. *, ${ }^{* *}$, and ${ }^{* * *}$ indicate levels of significance at 10,5 , and 1 per cent.

Source: Author's compilation based on study dataset.

Table A12: Static IV results relative wages (rural) dependent variable controlling for R\&D expenses.

\begin{tabular}{lc}
\hline Explanatory variables & $(1)$ \\
\hline Foreign share & $0.73^{* *}(0.27)$ \\
Training & $186.69(50.09)$ \\
Foreign sharexTraining & $0.0008^{* \star}(0.0003)$ \\
Indian share & $0.04(0.03)$ \\
$R \& D$ expenses & $-5.38(9.96)$ \\
Foreign share $x$ R\&D expenses & $-0.13(0.25)$ \\
Size & $0.0001^{* \star}(0.0004)$ \\
Size & $-3.83 e-09^{* \star *}(1.01 \mathrm{e}-09)$ \\
Constant $R^{2}$ & 0.76 \\
Kleibergen-Paap $r k$ LM statistic & 11.745 \\
Cragg-Donald Wald F statistic & 1.902 \\
Kleibergen-Paap $r k$ Wald F statistic & 2.388 \\
Constant & $-44.66^{* *}(14.09)$ \\
$N$ & 369 \\
\hline
\end{tabular}

Note: Robust standard errors are in parentheses. All specifications include full set of time and two-digit level industry dummies. ${ }^{*},{ }^{*}$, and ${ }^{* \star *}$ indicate levels of significance at 10,5 , and 1 per cent.

Source: Author's compilation based on study dataset.

Table A13: Static IV results relative wages (rural) dependent variable (investment-wise)

\begin{tabular}{lcc}
\hline Explanatory variables & High investment & Low investment \\
& $(1)$ & $(2)$ \\
\hline Foreign share & $0.98^{\star}(0.67)$ & $0.18^{* *}(0.06)$ \\
Training & $-1.70(1.55)$ & $30.77^{* *}(12.22)$ \\
Foreign share Training & $0.0008^{* \star}(0.0002)$ & $0.0003(0.0004)$ \\
Size & $0.0001(0.0008)$ & $0.0003^{* \star}(0.0004)$ \\
Size & $1.69 \mathrm{e}-10(2.50 \mathrm{e}-10)$ & $6.73 \mathrm{e}-09(1.48 \mathrm{e}-08)$ \\
Constant & $-62.66^{\star *}(40.03)$ & $-12.12^{* *}(4.00)$ \\
$R^{2}$ & 0.61 & 0.50 \\
Kleibergen-Paap rk LM statistic & 4.427 & 25.000 \\
Cragg-Donald Wald F statistic & 1.456 & 7.224 \\
Kleibergen-Paap rk Wald F statistic & 1.537 & 8.840 \\
$N$ & 549 & 490 \\
\hline
\end{tabular}

Note: Robust standard errors are in parentheses. All specifications include full set of time and two-digit level industry dummies. ${ }^{*},{ }^{*}$, and ${ }^{* * *}$ indicate levels of significance at 10,5 , and 1 per cent.

Source: Author's compilation based on study dataset. 